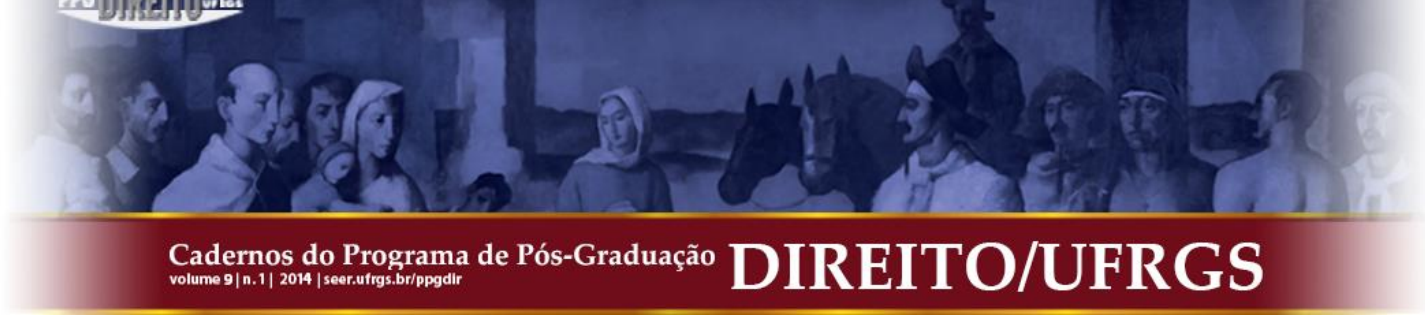

\title{
A DOUTRINA DO STANDING COMO UM ELEMENTO ESSENCIAL DA SEPARAÇÃO DE PODERES*
}

\author{
THE DOCTRINE OF STANDING AS AN ESSENTIAL ELEMENT OF THE SEPARATION OF \\ POWERS
}

\begin{abstract}
Antonin Scalia**
RESUMO: Minha tese é de que a doutrina judicial do Standing é um elemento crucial e inseparável do princípio da separação de poderes, cujo desrespeito produzirá, inevitavelmente, - como o fez durante as últimas décadas - uma judicialização excessiva do processo de autogoverno. Especificamente, sugiro que os tribunais precisam conferir maior peso do que o concedido nos últimos tempos ao requisito tradicional de que o dano alegado pelo autor seja distinguível do dos demais, separando-o da cidadania em sentido amplo.

PALAVRAS-CHAVE: Doutrina do Standing; Separação de Poderes; Lei do Processo Administrativo; Controle Judicial; Judicialização da Política.

ABSTRACT: My thesis is that the judicial doctrine of standing is a crucial and inseparable element of the principle of the separation of powers, whose disregard will inevitably produce - as it has during the past few decades - an overjudicialization of the process of selfgovernance. More specifically, I suggest that courts need to accord greater weight than they have in recent times to the traditional requirement that the plaintiff's alleged injury be a particularized one, which sets him apart from the citizenry at large.

KEY-WORDS: Standing Doctrine, Separation of Powers, Administrative Procedure Act - APA, Judicial Review, Courts converted into Political Forums.

SUMÁRIO: Introdução do tradutor. Introdução de Antonin Scalia. I. A doutrina do Standing. II. Mudanças recentes na doutrina. III. Standing e a separação de poderes. IV. A separação de poderes e os direitos dos indivíduos. V. Retorno ao entendimento original. Referências.
\end{abstract}

\section{INTRODUÇÃO DO TRADUTOR****}

A doutrina do Standing ${ }^{l}$ é um elemento essencial do sistema constitucional norteamericano e uma das principais teorias acerca da interpretação dos limites ao poder judiciário.

\footnotetext{
* Publicação original: SCALIA, Antonin. The Standing Doctrine as an Essential Element of the Separation of Powers. Suffolk University Law Review, Boston: Suffolk Law School, n. 17, p. 881-892, 1983. Disponível em http://heinonline.org/HOL/LandingPage?collection=journals\&handle=hein.journals/sufflr17\&div=62 \&id=\&page=. Acesso em 02 jan. 2013. Tradução de Romulo Ponticelli Giorgi Júnior. A publicação desta tradução e de sua introdução foram autorizadas pelo Justice Antonin Scalia no dia 27/06/2014. A tradução foi feita a pedido do Prof. Dr. Cezar Saldanha Souza Jr., para apresentação na disciplina DIRP139 - Seminários de Direito do Estado II - Processo e Constituição.

** Juiz da Suprema Corte dos Estados Unidos da América desde 26/09/1986, é o mais antigo dos juízes em atividade na Suprema Corte. Nascido em 11/03/1936, formado em história pela Georgetown University, em Washington, D. C. e pela Universidade de Friburgo, na Suíça, em 1957, e em Direito pela Harvard University, em 1961. Advogou de 1961 a 1967. Lecionou nas Universidades da Virgínia e de Chicago e é Professor visitante na Georgetown University e em Stanford. Foi Procurador-Geral da Secretaria de Políticas de Telecomunicação e Procurador-Geral Adjunto e Desembargador Federal. Dirigiu o setor de Dir. Adm. da American Bar Association. $\mathrm{Na}$ época em que redigiu este artigo, Scalia era Desembargador Federal da Corte de Apelações do Distrito de Colúmbia. Este artigo é uma versão revisada da nona Palestra Donahue na Faculdade de Direito da Universidade de Suffolk.

**** O tradutor, Romulo Ponticelli Giorgi Júnior, é mestre e doutorando em Direito Constitucional pela UFRGS, Procurador da Fazenda Nacional e Professor de Direito Constitucional na Faculdade São Judas Tadeu. Foi Procurador do Município de Porto Alegre, Procurador do Estado do Rio Grande do Sul e Advogado da União.
} 


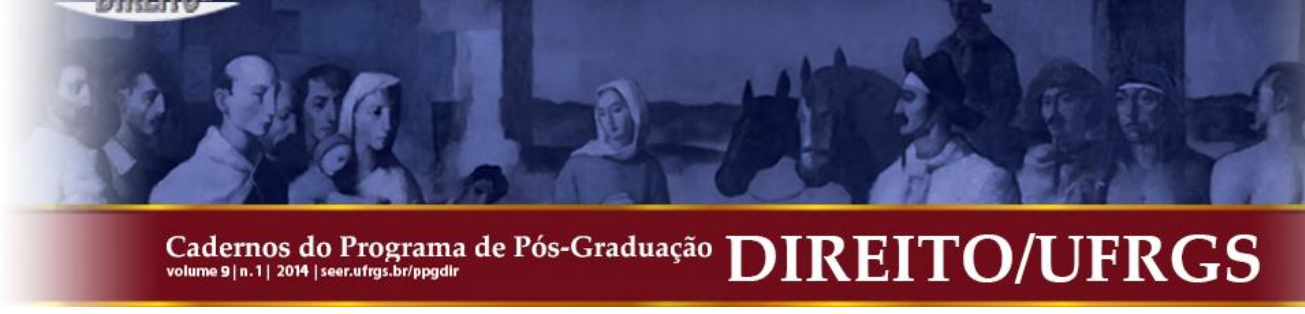

Os Profs. Jerome A. Barron e C. Thomas Dienes, no seu Manual de Direito Constitucional, colocam a doutrina do Standing como um dos três limites ao controle judicial, o limite subjetivo. Os outros dois são o limite temporal, analisado nas regras contra a irrelevância, a abstração e a prematuridade das ações e o limite objetivo do controle judicial, analisado na doutrina das questões políticas ${ }^{2}$.

No Brasil o princípio da inafastabilidade do controle judicial (CF, art. $\left.5^{\circ}, \mathrm{XXXV}\right)$ tem sido historicamente relacionado com a famosa cláusula do devido processo, estabelecida na $5^{\mathrm{a}}$ Emenda à Constituição dos EUA (CEUA), embora Pontes de Miranda já salientasse que: “em todo caso, no sistema jurídico brasileiro, o controle judicial vai muito mais longe do que nos outros sistemas jurídicos, inclusive no dos Estados Unidos da América”.”.

Nos Estados Unidos a doutrina do standing é vista como uma análise, primariamente, do art. III da Constituição dos EUA, em face do extenso tratamento autônomo conferido à cláusula do devido processo.

Entretanto, como a doutrina do standing opera também como delimitadora do direito de ação e do princípio da inafastabilidade do judiciário, ela interpreta em conjunto a $5^{\text {a }}$ Emenda e o disposto nas seções $1^{\mathrm{a}}$ e $2^{\mathrm{a}}$ do art. $3^{\mathrm{o}}$ da CEUA, que dispõe sobre o Poder Judiciário; bem como dos limites do controle sobre os atos do Poder Executivo, proferidos

\footnotetext{
${ }^{1}$ Na maior parte das situações, o standing pode ser traduzido por direito concreto de ação, entendido da mesma forma como esta expressão é utilizada normalmente no Brasil. Assim, se dizemos que "A tem direito de ação diante de B" a expressão direito de ação corresponderia ao uso mais frequente de standing, ou seja, de direito concreto de ação diante de uma situação jurídica e réu específicos. Ocorre que, em várias situações ao longo do artigo de Scalia e da doutrina constitucional norte-americana, standing também é utilizado no sentido de direito abstrato de ação, e mesmo em uma pluralidade de outros sentidos, envolvendo os limites do Poder Judiciário diante do Executivo e, principalmente, do Legislativo. Uma parte significativa do artigo de Scalia lida com a doutrina do standing no sentido de delimitação da possibilidade de imposição de limites legislativos ao direito de ação.

A compreensão do standing exige a identificação, claramente delineada por Scalia neste artigo, de uma divisão bipartida da doutrina do standing pela Suprema Corte:

I) O primeiro sentido é o de direito concreto de ação, limitável jurisprudencialmente, podendo o legislativo ampliar o direito de ação, removendo legislativamente obstáculos jurisprudenciais;

II) O segundo sentido é o núcleo constitucional do standing, referindo o requisito mínimo de dano ajuizável que nem o Congresso pode eliminar (SCALIA, 1983, p. 882).

Scalia entende que a divisão bipartida é insuficiente para a compreensão integral do standing, pois haveria um terceiro sentido, igualmente integrado ao seu núcleo constitucional e à própria essência do common law:

III) O terceiro sentido, integrado tanto ao núcleo constitucional do standing como à essência do common law, diz respeito à imposição de limites jurisprudenciais pelos tribunais à possibilidade do Congresso converter interesses coletivos em direitos subjetivos (SCALIA, 1983, p. 886).

${ }^{2}$ BARRON, Jerome A. \& DIENES, C. Thomas. Constitutional Law in a nutshell. 7th ed. St. Paul, MN: West, 2009, cap. I, itens I.D.1 a I.D.3 (ebook).

${ }^{3}$ MIRANDA, Pontes de. Comentários à Constituição de 1967 com a Emenda n. I de 1969. São Paulo: Revista dos Tribunais, 1971, tomo V, p. 106.
} 


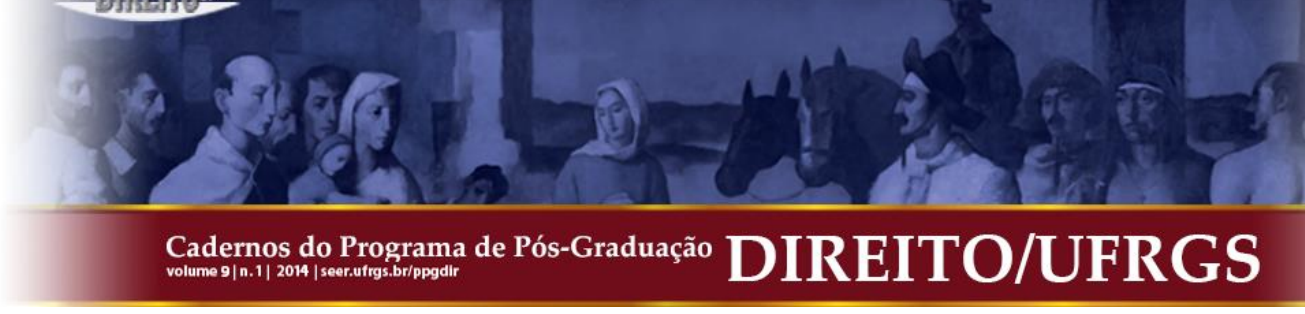

com base no art. $2^{\circ}$ da CEUA, e do Poder Legislativo, proferidos com base no art. $1^{\circ}$ da CEUA.

A doutrina do Standing, tal como entendida pela Suprema Corte dos EUA, baseia-se em um único princípio, o da separação de poderes, restringindo os casos e controvérsias ajuizáveis e permitindo às cortes recusar o direito de ação à demandas mais adequadas ao processo político. Finalmente, a doutrina do Standing, para a Suprema Corte, e especialmente para Scalia, serviria como um delimitador constitucional dos poderes constituídos, prevenindo avanços legislativos que limitassem os tribunais em seu controle das atividades do Poder Executivo ${ }^{4}$.

Como a doutrina do standing analisa o direito de ação e os limites constitucionais que envolvem o princípio da inafastabilidade do judiciário, que é visto no Brasil como diretamente derivado da cláusula do devido processo, incluído na CEUA pela sua $5^{\text {a }}$ Emenda, traduzimos abaixo o texto da $5^{\text {a }}$ Emenda à Constituição dos Estados Unidos, para facilitar a compreensão da discussão pelos brasileiros.

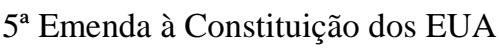

Ninguém pode ser detido para responder a um crime capital, ou infame, senão por meio da apresentação ou indiciamento de um Grande Júri, excetuados os casos ocorridos no Exército, na Marinha e na Guarda Civil, quando em serviço ativo em tempos de guerra ou de perigo público. Ninguém pode ser submetido pelo mesmo fato duas vezes a risco de vida ou à integridade corporal, nem ser compelido em nenhum processo criminal a ser testemunha contra si mesmo. Ninguém será privado da vida, da liberdade ou da propriedade, sem o devido processo. A propriedade privada não pode ser tomada para uso público sem a devida compensação ${ }^{5}$.
\end{abstract}

O artigo abaixo traduzido foi publicado em 1983, quando Scalia ainda era Desembargador, antes de sua nomeação para a Suprema Corte dos EUA, em 1986, por Ronald Reagan. Scalia nasceu em 1936, em uma família católica, cresceu no Queens, em Nova Iorque, graduou-se em história na Georgetown University, em Washington, D. C., onde ingressou em 1953. Iniciou seus estudos de Direito em Harvard, em 1957. Tem nove filhos.

\footnotetext{
${ }^{4}$ ELLIOT, Heather. The Functions of Standing. Stanford Law Review, Stanford, California: Stanford University, v. 61, n. 3, 2008. Disponível em <http://www.questia.com/read/1G1-195917973>. Acesso em 28 abr. 2014.

${ }^{5}$ ESTADOS UNIDOS DA AMÉRICA. CONSTITUIÇÃO (1787). Washington: Senado, 2014. Disponível em $\langle$ http://www.senate.gov/civics/constitution_item/constitution.htm>. Acesso em 28 abr. 2014. A Constituição dos EUA tem 26 emendas, a última delas promulgada em 1971. A 5 a Emenda foi promulgada em conjunto com as demais 10 primeiras emendas, em 1791. Amendment 5. No person shall be held to answer for a capital, or otherwise infamous crime, unless on a presentment or indictment of a Grand Jury, except in cases arising in the land or naval forces, or in the Militia, when in actual service in time of War or public danger; nor shall any person be subject for the same offense to be twice put in jeopardy of life or limb; nor shall be compelled in any criminal case to be a witness against himself, nor be deprived of life, liberty, or property, without due process of law; nor shall private property be taken for public use, without just compensation.
} 


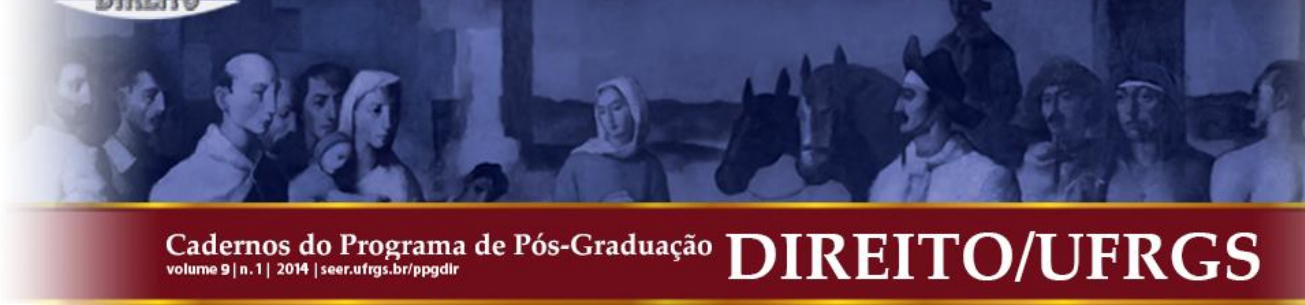

Scalia iniciou sua atividade como advogado em 1961. Em 1967 começou a lecionar direito na Universidade de Virgínia. Em 1972 foi nomeado por Nixon para o cargo de Procurador-Geral da Secretaria de Políticas de Telecomunicação. Em 1974 foi nomeado Procurador-Geral Adjunto na Advocacia Pública Federal. Foi nomeado desembargador federal em Washington, D. C., em 1982 por Ronald Reagan. Integra a Suprema Corte dos EUA desde $1986^{6}$.

\section{INTRODUÇÃO DE ANTONIN SCALIA}

O princípio da separação de poderes foi estabelecido na Constituição da Comunidade de Massachusetts muito antes de sua inserção na Constituição federal norte-americana. Lemos na Constituição de Massachusetts, com advocatícia (e algo tediosa) clareza:

o Poder Legislativo nunca deve exercer os poderes judiciais e executivos, nem nenhum deles; o Poder Executivo nunca deve exercer os poderes legislativos e judiciais, nem nenhum deles; o Poder Judiciário nunca deve exercer os poderes legislativos e executivos, nem nenhum deles ${ }^{7}$.

O texto prossegue, enfatizando a importância conferida a esta provisão, aduzindo: "com a finalidade de que tenhamos um governo das leis, e não dos homens" - como se esta característica, acima de todas as demais, pudesse assegurar a ausência de despotismo.

A prescrição federal sobre o tema não é tão completa. De fato, com uma economia de expressão que muitos propõem como modelo para as decisões judiciais modernas, o princípio da separação de poderes é encontrado apenas na estrutura do documento, que descreve sucessivamente os âmbitos dos Poderes Legislativo, Executivo e Judiciário ${ }^{8}$. Não podemos pensar, entretanto, que o princípio fosse menos importante para os constituintes. A este

6 BIOGRAFY.COM WEBSITE. Antonin Gregory Scalia. [s.1.]: biografy.com, 2014. Disponível em <http://www.biography.com/people/antonin-scalia-9473091\#supreme-courtjustice\&awesm= oCUXaRtFGeMbfd>. Acesso em 30 abr. 2014.

7 N. do T. MASSACHUSETTS. Constituição (1780). Boston: The General Court, 2014, Parte 1, art. 30. Disponível em https://malegislature.gov/Laws/Constitution. Acesso em 03 mai. 2014. A Constituição de Massachusetts tem duas partes, a primeira contendo a Declaração de Direitos dos Habitantes da Comunidade de Massachusetts, tinha 30 artigos. A segunda parte dispõe sobre a estruturação do governo.

Article XXX. In the government of this commonwealth, the legislative department shall never exercise the executive and judicial powers, or either of them: the executive shall never exercise the legislative and judicial powers, or either of them: the judicial shall never exercise the legislative and executive powers, or either of them: to the end it may be a government of laws and not of men.

${ }^{8}$ N. do T. ESTADOS UNIDOS DA AMÉRICA. Constituição (1787). Washington: Senate, [2014], art. I, § 1 ${ }^{\circ}$; art. II, $\S 1^{\circ}$ e art. III, $\S 1^{\circ}$. Disponível em http://www.senate.gov/civics/constitution_item/constitution.htm. Acesso em 03 mai. 2014. 


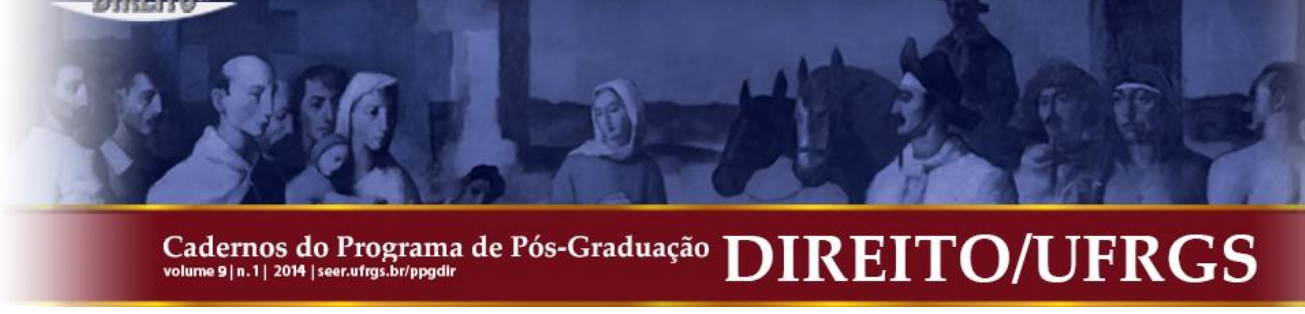

respeito disse Madison, no Federalista, no escrito 47, que: “certamente, nenhuma verdade política tem maior valor intrínseco, nem está chancelada com a autoridade de mais

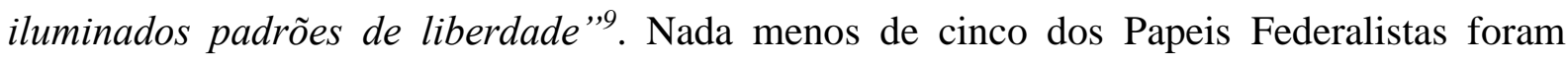
devotados à demonstração de que o princípio era observado adequadamente na Constituição $\operatorname{proposta}^{10}$.

Minha tese é de que a doutrina judicial do standing é um elemento crucial e inseparável deste princípio, cujo desrespeito produzirá, inevitavelmente, - como o fez durante as últimas décadas - uma judicialização excessiva do processo de auto-governo ${ }^{11}$. Especificamente, sugiro que os tribunais precisam conferir maior peso do que o concedido nos últimos tempos ao requisito tradicional de que o dano alegado pelo autor seja distinguível do dos demais, separando-o da cidadania em sentido amplo.

\section{A DOUTRINA DO STANDING}

A Suprema Corte tem descrito o standing como "uma base suficiente em uma demanda ajuizável para obter a resolução judicial desta controvérsia" ${ }^{12}$. Simplificando, é uma resposta à primeira questão que é às vezes indagada rudemente quando alguém reclama das ações de outrem: “o que é isto para você?”. O requisito do standing tem integrado o direito constitucional norte-americano por meio (na busca de um melhor veículo) da disposição do art. III, Seção 2, que dispõe que: “o Poder Judiciário deve estender-se" a certos "Casos" e "Controvérsias" $"$. Na ausência de caso ou controvérsia, não se aplica o raciocínio jurídico, quando não haja partes adversas com interesse pessoal no assunto ${ }^{14}$. Não se trata, certamente, de uma conclusão linguisticamente inevitável, mas é, ainda assim, uma descrição acurada da espécie de atividade com que os tribunais tradicionalmente se envolvem, e portanto da

\footnotetext{
${ }^{9}$ HAMILTON, Alexander; MADISON, James \& JAY, John. The Federalist. Indianapolis: Liberty Fund, 2001, escrito n. 47, de James Madison.

${ }^{10}$ Ibidem, escritos $n^{\circ}$ s 47, 48 e 49 (James Madison), 50 e 51 (Alexander Hamilton ou James Madison).

${ }^{11}$ Veja HOROWITZ, Donald L. The Courts and Social Policy. Washington, D. C.: The Brookings Institution, 1977, pp. 4-5.

${ }^{12}$ ESTADOS UNIDOS. SUPREMA CORTE. Sierra Club v. Morton, 405, U.S. 727, p. 731, 1972. Disponível em https://supreme.justia.com/cases/federal/us/405/727/case.html. Acesso em 03 mai. 2014.

${ }^{13}$ Constituição dos EUA, art. III, § 2.

14 Veja ESTADOS UNIDOS. SUPREMA CORTE. Muskrat v. United States, 219 U. S. 346, p. 357, 1911. Disponível em https://supreme.justia.com/cases/federal/us/219/346/case.html. Acesso em 04 mai. 2014; ESTADOS UNIDOS. SUPREMA CORTE. United States v. Ferreira, 54 U. S. (13 How) 40, p. 46 (1851). Disponível em http://supreme.justia.com/cases/federal/us/54/40/case.html. Acesso em 04 mai. 2014; ESTADOS UNIDOS. SUPREMA CORTE. Hayburn's Case, 2 U. S. (2. Dall.) 409 (1792). Disponível em http://supreme.justia.com/cases/federal/us/2/409/. Acesso em 04 mai. 2014.
} 


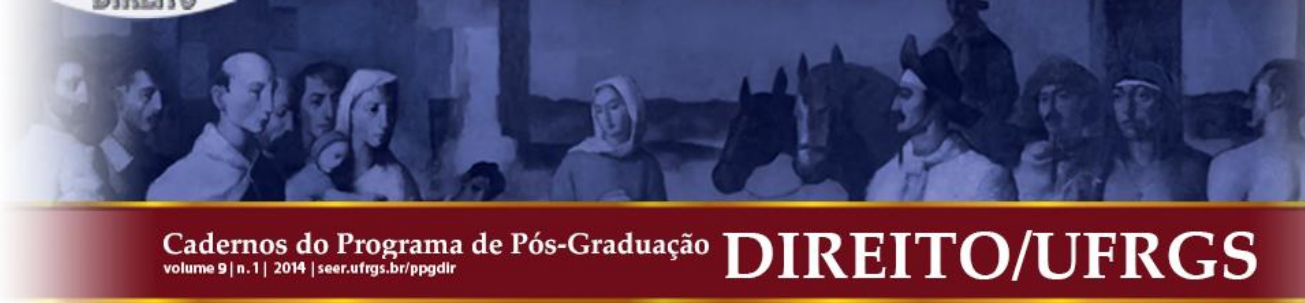

peculiar atividade à qual eles se supõem limitados em face da Constituição. É interessante ver o quão claro parecia ser, para os constituintes, a tarefa própria do Judiciário. No texto $\mathrm{n}^{\circ} 48$ do Federalista, descrevendo a razão do Legislativo ser o mais perigoso dos poderes, Madison diz:

\begin{abstract}
Não é incomum uma questão de verdadeira beleza nos corpos legislativos, se uma operação ou medida particular irá, ou não, estender-se além da esfera legislativa. Por outro lado, estando o Poder Executivo limitado a uma campo mais restrito e sendo mais simples em sua natureza, e o Judiciário sendo descrito por fronteiras ainda mais definidas, tentativas de usurpação por qualquer destes poderes iria imediatamente traí-los e derrotá- $\operatorname{los}^{15}$.
\end{abstract}

Poucos comentadores modernos veriam esta clareza nas fronteiras que delimitam a tarefa do judiciário ${ }^{16}$. De fato, comparativamente as restrições sobre o modo e o âmbito das atividades do Legislativo e do Executivo são um modelo de definitividade.

A mudança de ares que ocorreu na atitude judicial diante da doutrina do standing particularmente no que pertine à intromissão judicial nas atividades dos dois outros poderes torna-se evidente quando se comparam decisões recentes com o primeiro caso no qual a Suprema Corte contemplou a interferência com as atividades de alto nível do Executivo, evitando tal interferência apenas interferindo com um ato legislativo. Em Marbury v. Madison $^{17}$, a Suprema Corte estava preocupada que a concessão de um mandamus diante do Secretário de Estado, determinando a entrega do ato de nomeação do Sr. Marbury no judiciário, "poderia, à primeira vista, ser considerada por alguns como uma invasão dentro do gabinete [do Presidente], e como uma intromissão com as prerrogativas do Poder Executivo" 18 . A Suprema Corte respondeu a este temor afirmando:

Dificilmente haveria a necessidade da Suprema Corte renunciar a todas as pretensões a uma tal jurisdição. Uma extravagância, de tal modo absurda e excessiva, não poderia ser cogitada por um minuto sequer. A atividade do Judiciário é, apenas, a de decidir os direitos dos indivíduos, e não a de perquirir como o Executivo, ou os funcionários do Executivo, executam deveres para os quais dispõem de discricionariedade ${ }^{19}$.

\footnotetext{
${ }^{15}$ HAMILTON, MADISON, JAY, 2001, escrito n. 48, de James Madison.

${ }^{16}$ Compare FULLER, Lon L. The Forms and Limits of Adjudication. Harvard Law Review, vol. 92, n. 2, Dec. 1978, $\quad$ pp. 353-409, $\quad$ disponível em <http://www.jstor.org/discover/10.2307/1340368?uid=3737664\&uid=2129\&uid=2\&uid=70\&uid=4\&sid=21101 310094827>, acesso em 20/11/2011 com CHAYES, Abram. The Role of the Judge in Public Law Litigation. Harvard Law Review, vol. 89, p. 1.281, 1976.

${ }^{17}$ ESTADOS UNIDOS. SUPREMA CORTE. Marbury v. Madison, 5 U. S. (1 Cranch) 137 (1803). Disponível em http://supreme.justia.com/cases/federal/us/5/137/case.html. Acesso em 05 mai. 2014.

${ }^{18}$ Ibidem, pp. 169-170.

${ }^{19}$ Ibidem, p. 170.
} 


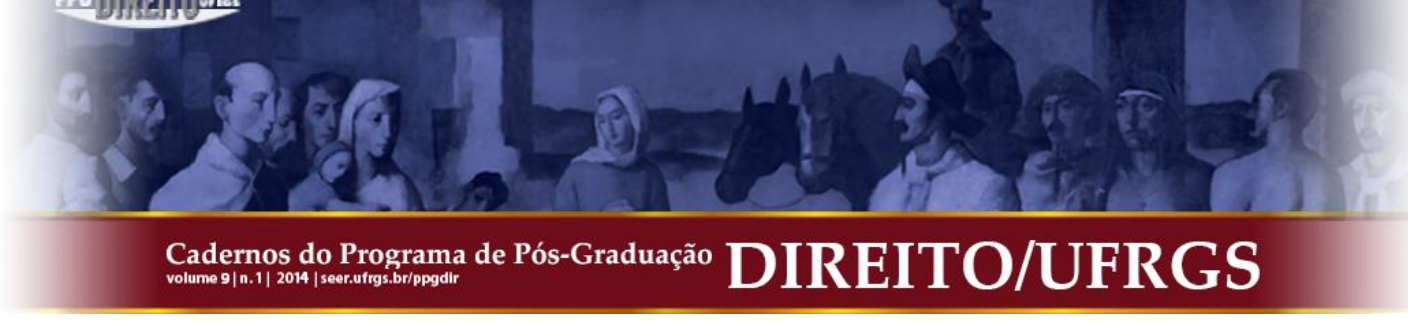

Uma atitude semelhante é refletida posteriormente, já em 1944, em Stark v. Wickard ${ }^{20}$, uma decisão da Suprema Corte sobre os limites da judicialidade (generosa para os seus dias), que permitiu que os produtores de leite se contrapusessem a uma portaria do Ministério da Agricultura sobre a comercialização do leite:

Quando ... direitos pessoais claros são criados por normas federais, semelhantes na espécie àqueles [direitos] tratados costumeiramente pelos tribunais, o silêncio do Congresso quanto ao seu controle judicial não deve, principalmente na ausência de um remédio administrativo, ser interpretado como uma denegação à pessoa agravada do acesso às cortes federais.

... Quando o Congresso aprova uma lei conferindo poderes às agências administrativas para a realização de tarefas governamentais, o poder destas agências é limitado pela autoridade conferida. Isto permite que o Judiciário participe da aplicação e do cumprimento do direito confiado aos entes administrativos apenas na medida necessária à proteção de direitos individuais ajuizáveis diante de ações administrativas que estão claramente além dos poderes concedidos [às agências] ... Isto está muito longe de afirmar que os tribunais estejam mais encarregados do que os legisladores ou os administradores com a proteção dos direitos do povo. O Congresso e o Executivo supervisionam as atividades dos agentes administrativos ... Estes Poderes tem o pessoal e os recursos [necessários] para examinar as tarefas dos vários estabelecimentos para determinar as mudanças necessárias ao seu funcionamento ou gerenciamento. Sob o art. III da Constituição, o Congresso criou os órgãos do Poder Judiciário para julgar os casos e controvérsias, assim como as reclamações diante da infringência de direitos individuais, seja pela ação ilícita de pessoas privadas, seja pelo exercício de poder administrativo não autorizado ${ }^{21}$.

Compare estas descrições da "matéria ajuizável" com o parágrafo de abertura da decisão da Corte de Apelações de 1971 no caso limite Calvert Cliffs ${ }^{22}$, que iniciou o longo caso de amor do judiciário com a litigância envolvendo a proteção do meio-ambiente:

Estes processos são apenas o começo do que promete tornar-se um dilúvio de nova litigância - litigância buscando apoio judicial para a proteção ao meioambiente. Várias normas recentemente promulgadas certificam o comprometimento governamental no controle, finalmente, da destrutiva máquina do "progresso" material. Mas ainda precisamos nos certificar de que a promessa desta legislação se tornará realidade. Aí reside o papel do Judiciário. Nestes casos, nós tivemos de interpretar, pela primeira vez, a mais ampla e talvez a mais genérica destas normas: a Lei da Política Nacional do Meio Ambiente (National Environment Policy Act NEPA), de 1969. Nós temos de avaliar reclamações de que uma das agências encarregadas com a sua administração falhou em cumprir o mandamento do Congresso. Nosso dever, em síntese, é velar para que importantes propósitos

${ }^{20}$ ESTADOS UNIDOS. SUPREMA CORTE. Stark v. Wickard, 321 U. S. 288 (1944). Disponível em http://supreme.justia.com/cases/federal/us/321/288/case.html. Acesso em 05 mai. 2014.

${ }^{21}$ Ibidem, pp. 309-310.

${ }^{22}$ ESTADOS UNIDOS. WASHINGTON, D. C. APPELLATE COURT. Calvert Cliffs Coordinating Comm'n v. Atomic Energy Comm'n, 449 F. 2d. $1109 \quad$ (D.C. Cir. 1971). Disponível em http://law.justia.com/cases/federal/appellate-courts/F2/449/1109/240994/. Acesso em 05 mai. 2014. 


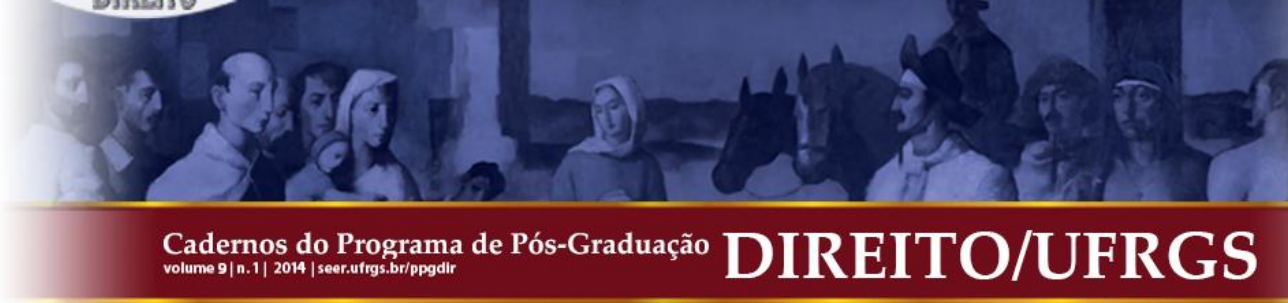

legislativos, proclamados nos halls do Congresso, não se percam nem se deturpem nos amplos corredores da burocracia federal ${ }^{23}$.

Seria um erro pensar que a diferença entre as duas primeiras decisões e esta última representa apenas o efeito do realismo jurídico - um reconhecimento saudável, após anos de ficções enevoadas, que os tribunais asseguram de fato (nos anos 198X assim como em 1803) a regularidade das ações do Executivo. [A mudança] vai além disto. O ponto não é se os tribunais o fizeram; mas se a realização disto [da proteção ao meio-ambiente] é, isoladamente, justificação suficiente para a invocação destes poderes; se a realização disto é inerente ao "papel do judiciário", ou antes meramente o efeito incidental do que Marbury v. Madison nos levou a considerar como o papel próprio dos juízes - "unicamente, decidir sobre os direitos dos indivíduos" ${ }^{24}$. Que houve uma mudança na função, ao invés de meramente na percepção [do papel do Judiciário e dos juízes], parece visível pela comparação da descrição detalhada dos interesses individuais do Sr. Marbury ${ }^{25}$ em Marbury v. Madison; assim como na descrição do interesse dos produtores de leite autores em Stark v. Wickard ${ }^{26}$, com a descrição do interesse dos autores no caso Calvert Cliffs. O último [requisito] é fácil de demonstrar, pois não existe na realidade. Lendo a decisão, não se consegue entender se o Comitê de Coordenação dos Penhascos Calvert, que paralisou a construção da Usina Nuclear de Calvert Cliff, era composto por ecologistas, ou proprietários de terras adjacentes à área onde a usina seria construída, ou por empresas concorrentes operadoras de termelétricas a base de carvão, ou até, imaginemos, um grupo de engenheiros militares, que são conhecidos por preferirem barragens às usinas nucleares. Para a Suprema Corte de 1971, a questão [do interesse real dos autores] não tinha importância.

\section{MUDANÇAS RECENTES NA DOUTRINA}

Após descrever a mudança, deixe-me tentar explicar como e porque ela ocorreu. Devemos atentar, inicialmente, para uma característica peculiar do standing: o fato de que sua existência em uma determinada ação está amplamente dentro do controle do Congresso.

\footnotetext{
${ }^{23}$ Ibidem, p. 1111.

24 ESTADOS UNIDOS. SUPREMA CORTE. Marbury v. Madison, 5 U. S. (1 Cranch) 137, 170 (1803). Disponível em http://supreme.justia.com/cases/federal/us/5/137/case.html. Acesso em 05 mai. 2014.

${ }^{25}$ Ibidem, pp. 154-162.

${ }^{26}$ ESTADOS UNIDOS. SUPREMA CORTE. Stark v. Wickard, 321 U. S. 288 (1944), pp. 303-304. Disponível em http://supreme.justia.com/cases/federal/us/321/288/case.html. Acesso em 05 mai. 2014.
} 


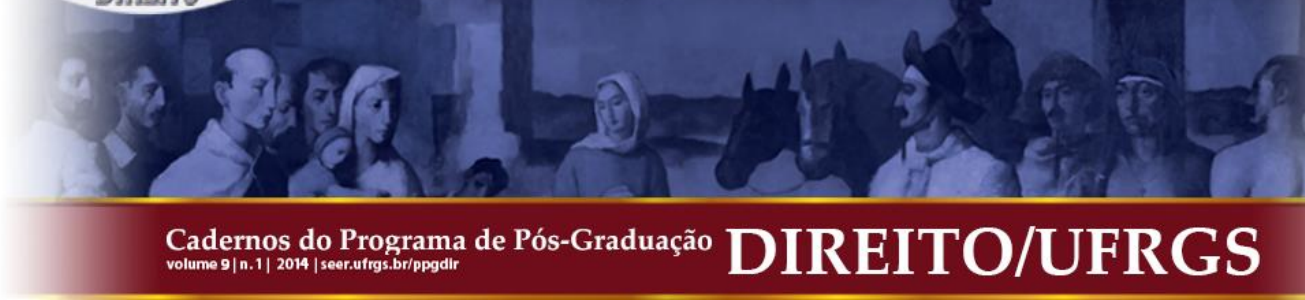

Standing requer, como referido anteriormente, a alegação de um dano particularizável individualmente ao autor. Mas o dano jurídico (legal injury) não é nada mais do que a violação de um direito (legal right); e os direitos podem ser criados pelo legislativo. Portanto, o meu direito de ação (standing) para opor-me à construção de um posto de gasolina pelo meu vizinho, erguido em violação ao zoneamento estabelecido no Plano Diretor, dependerá do legislativo conceder-me pessoalmente um direito a liberar-me desta ação [do vizinho]. $\mathrm{O}$ legislativo pode, entretanto, optar por deixar a fiscalização e a exigência do cumprimento do zoneamento estabelecido no Plano Diretor (tal como ocorre com as limitações das áreas de estacionamento na rua na frente da minha casa) exclusivamente a cargo das autoridades públicas. A Suprema Corte decidiu levar em conta este elemento do controle legislativo do direito de ação, dividindo a doutrina do standing em duas partes separadas. A primeira parte consiste dos denominados "limites jurisprudenciais do direito de ação", supostamente impostos pelo próprio tribunal, sujeitos à eliminação pela Suprema Corte ou pelo Congresso. Esta parte explica aquelas inúmeras situações, tais como o exemplo do zoneamento urbano acima fornecido, nas quais o direito de ação, denegado no passado, será a seguir reconhecido, após a aprovação de uma norma (statute) removendo (tal como entende a Suprema Corte) o antigo obstáculo judicial ao direito de ação ${ }^{27}$. A segunda parte é o núcleo constitucional do standing, um requisito mínimo de dano ajuizável que nem mesmo o Congresso pode eliminar ${ }^{28}$. Pessoalmente, acho esta bifurcação insatisfatória - principalmente por que ela não explica a fonte da autoridade do tribunal para simplesmente conceder ou denegar o direito de ação como sua prudência possa ditar. Como eu preferiria ver a matéria, o juízo deveria sempre ouvir o caso de um autor que alegasse a violação de um direito. Em alguns casos, a existência desse direito é, com base nas nossas tradições do common law, inteiramente clara - como é caso, por exemplo, quando uma disposição normativa exige que um agente do Poder Executivo providencie um benefício específico para um indivíduo determinado. (Esta é a espécie de direito afirmada em Marbury v. Madison). Em outros casos, entretanto, a intenção legislativa de criar um direito é muito mais problemática - por exemplo, quando o Congresso exige que o Poder Executivo implemente um programa geral (como a proteção ao meio

\footnotetext{
${ }^{27}$ Compare ESTADOS UNIDOS. SUPREMA CORTE. Warth v. Seldin, 422 US 490, 512-14 (1975). Disponível em http://supreme.justia.com/cases/federal/us/422/490/. Acesso em 03 mai. 2014 com ESTADOS UNIDOS. SUPREMA CORTE. Trafficante v. Metropolitan Life Ins. Co., 409 US 205, 212 (1972) (voto do Ministro de White, J., acompanhando o voto condutor). Disponível em http://supreme.justia.com/cases/federal/us/409/205/. Acesso em 03 mai. 2014.

${ }^{28}$ Warth v. Seldin, 422 US 490, 498-501 (1975). Referência eletrônica na nota anterior.
} 
ambiente) que melhorará a qualidade de vida de muitos indivíduos. Nestes casos, tal como eu vejo a matéria, os tribunais aplicam os vários fatores jurisprudenciais, não em virtude de sua autoridade inerente para expandir ou restringir o direito de ação, mas antes como um conjunto de pressupostos derivados da tradição do common law estabelecidos para determinar quando existe um direito. Portanto, quando o legislativo diz explicitamente que existe um direito individual existe, este denominado questionamento jurisprudencial está deslocado. Ultimamente, entretanto (como analisarei em mais detalhes abaixo), há um limite até mesmo sobre o poder do Congresso em converter interesses coletivos em direitos subjetivos - e esta é a limitação imposta pelo denominado requisito central do standing. Trata-se de uma limitação, tal como eu a entendo, apenas sobre o poder do Congresso de conferir direito de ação, não atingindo os tribunais, pois o judiciário sequer tem o poder de conferir direito de ação.

Em qualquer caso, utilizando a própria terminologia atual da Suprema Corte, o judiciário federal tem mostrado uma grande prontidão nos últimos anos para compreender a eliminação, pelo Congresso, de obstáculos jurisprudenciais tradicionais ao direito de ação no que pertine aos desafios à atividade do Poder Executivo. Primeiramente, conferiu-se uma interpretação extensiva às disposições relativas ao direito de ação em normas envolvendo direito material. No famoso caso Scenic Hucdson ${ }^{29}$, por exemplo, envolvendo a aprovação pelo Comitê Federal de Energia (Federal Power Commission - FPC) do projeto da hidrelétrica Storm King, o Tribunal Regional Federal do $2^{a}$ Região entendeu que a antiga norma da Lei Federal da Energia que conferia direito de ação às partes "lesadas" incluía "aqueles cuja conduta e atividades demonstrarem um especial interesse" "na estética, na conservação e no [impacto sobre o] âmbito recreativo do desenvolvimento energético" ${ }^{30}$. Uma

\footnotetext{
${ }^{29}$ ESTADOS UNIDOS. UNITED STATES COURT OF APPEALS 2ND CIRCUIT. Scenic Hudson Preservation Conference v. FPC, 354 F2d 608 (2d Circ. 1965). Disponível em http://law.justia.com/cases/federal/appellatecourts/F2/354/608/151121/. Acesso em 03 mai. 2014; certiorari denegado pela Suprema Corte: ESTADOS $\begin{array}{llllllll}\text { UNIDOS. } & \text { SUPREMA } & \text { CORTE. } & 384 & \text { US } & 941 & \text { (1966). Disponível em }\end{array}$ http://supreme.justia.com/cases/federal/us/386/372/case.html. Acesso em 03 mai. 2014.

${ }^{30}$ Scenic Hudson Preservation Conference v. FPC, 354 F 2d. at 616 (decisão acima referida, com endereço eletrônico para acesso).

Embora a Suprema Corte, em trechos de acórdãos não integrantes da ratio decidendi (obiter dictum) tenha, desde então, referido o trecho entre aspas com aprovação, ele não parece ser conforme o direito vigente. Apoiando, em dictum, o trecho entre aspas, veja-se ESTADOS UNIDOS. SUPREMA CORTE. Association of Data Processing Services, Inc. v. Camp., $397 \quad$ U.S. 150, $154 \quad$ (1970). Disponível em http://supreme.justia.com/cases/federal/us/397/150/case.html. Acesso em 03 mai. 2014. Em sentido contrário: ESTADOS UNIDOS. SUPREMA CORTE. Sierra Club v. Morton, 405 U.S. 727 (1972). Disponível em https://supreme.justia.com/cases/federal/us/405/727/case.html. Acesso em 03 mai. 2014.
} 


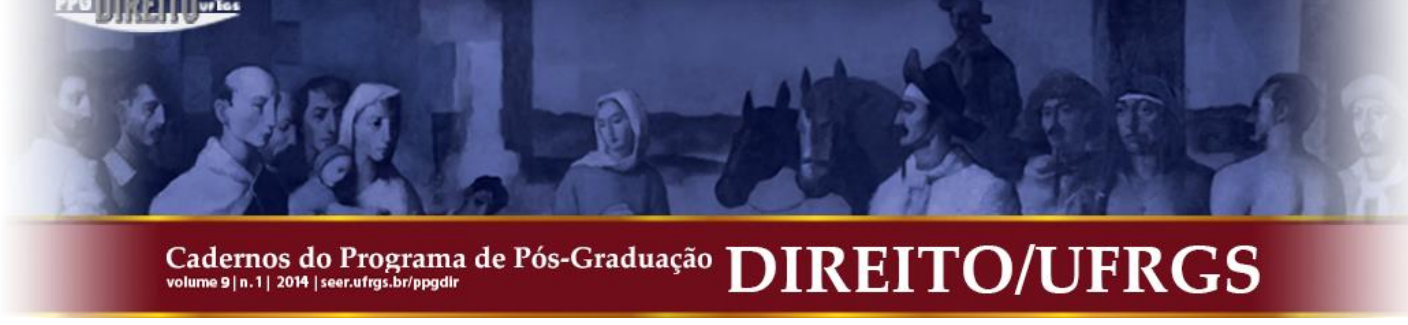

tal extensão do direito de ação seria impensável nos anos 40 - e acima de tudo quando a Lei Federal da Energia foi aprovada ${ }^{31}$.

Um desenvolvimento ainda mais importante tem sido a interpretação da Lei do Processo Administrativo para criar disposições permissivas do controle administrativo onde elas não existiam anteriormente. Vale apenas dedicar um tempo para explicar este desenvolvimento, que teve enormes consequências. A disposição que regulava o direito de interpor ações de controle dos atos administrativos na Lei do Processo Administrativo de 1947 dispunha que "qualquer pessoa sofrendo dano juridicamente reconhecido devido à ação de qualquer agência, ou afetada negativamente ou agravada por tal ação no sentido de qualquer norma relevante, tem o direito de interpor uma ação para o controle do ato" 32 . Um dano "juridicamente reconhecido" (“legal” wrong), evidentemente, pode apenas significar um dano já reconhecido nos tribunais - ou seja, um dano para o qual já havia sido reconhecido o direito de ação de acordo com os princípios tradicionais ${ }^{33}$. E a expressão

\footnotetext{
${ }^{31}$ Veja-se a interpretação parcimoniosa do mesmo tribunal da expressão "afetados negativamente", constante das disposições sobre o direito de ação da Lei sobre Alimentos, Remédios e Cosméticos no caso ESTADOS UNIDOS. UNITED STATES COURT OF APPEALS 2ND CIRCUIT. American Lecithin Co. v. McNutt, 155 F 2d. 784, 785 (2d. Circ. 1946). Disponível em http://law.justia.com/cases/federal/appellatecourts/F2/155/784/1563758/. Acesso em 03 mai. 2014 e ESTADOS UNIDOS. UNITED STATES COURT OF APPEALS 2ND CIRCUIT. United States Cane Sugar Refiners' Ass'n v.McNutt, 138, F. 2d. 116, 119-120 (2d. Circ. 1943). Disponível em http://law.justia.com/cases/federal/appellate-courts/F2/138/116/1481644/. Acesso em 03 mai. 2014.

${ }^{32}$ ESTADOS UNIDOS. Administrative Procedure Act. Lei de 11 de junho de 1946, cap. 324, 60. Lei 237, 243, 5 United States Code $\$ 702$ (1982) (ênfase do autor). Disponível em http://uscode.house.gov/view.xhtml?req=granuleid:USC-prelim-title5-section702\&num=0\&edition=prelim.

Acesso em 04 mai. 2014.

${ }^{33}$ Um caso julgado pela Suprema Corte em 1939 expõe estes princípios tradicionais no trecho abaixo:

Os apelantes invocaram a doutrina segundo a qual alguém ameaçado com um dano especial e direto pelo ato de um agente governamental que, se não fosse a autorização normativa para a sua atuação, seria uma violação do seu direito, pode questionar a validade da norma em um processo contra o agente público. Este princípio não tem aplicação se o direito atacado não for reconhecido - tal como os derivados da propriedade, dos contratos, da proteção diante do esbulho possessório, ou embasados em uma norma que confira um privilégio.
}

ESTADOS UNIDOS. SUPREMA CORTE. Tennesse Elec. Power Co. v. TVA, 306 U. S., 118, 137-38 (1939) (notas de rodapé omitidas). Disponível em http://supreme.justia.com/cases/federal/us/306/118/case.html. Acesso em 03 mai. 2014. A Suprema Corte prosseguiu, afirmando que a Companhia de Energia Elétrica de Tenessee não tinha direito de ação enquanto competidora da TVA (Tennesse Valley Authority - Autoridade do Vale do Tennessee), pois não tinha direito reconhecido (legal right) de livrar-se da concorrência. No mesmo sentido dispõe este acórdão, nas páginas 137-147.

Outros casos que exemplificam a interpretação restritiva conferida tradicionalmente à expressão "dano juridicamente reconhecido" ("legal wrong") como requisito do direito de ação são ESTADOS UNIDOS. SUPREMA CORTE. Perkins v. Lukens Steel Co., 310 U. S. 113, 125 (1940). Disponível em https://supreme.justia.com/cases/federal/us/310/113/case.html. Acesso em 03 mai. 2014, na qual se determinou que: "os produtores de ferro e de aço não tem direito de ação para contestar a definição do Ministro do Trabalho de diferenças locais relevantes para o estabelecimento de salários mínimos, pois ele não transgrediu direitos juridicamente reconhecidos"; ESTADOS UNIDOS. SUPREMA CORTE. Alabama Power Co. v. Ickes, 302 U.S. 464, 479-80 (1938). Disponível em https://supreme.justia.com/cases/federal/us/302/464/case.html. 


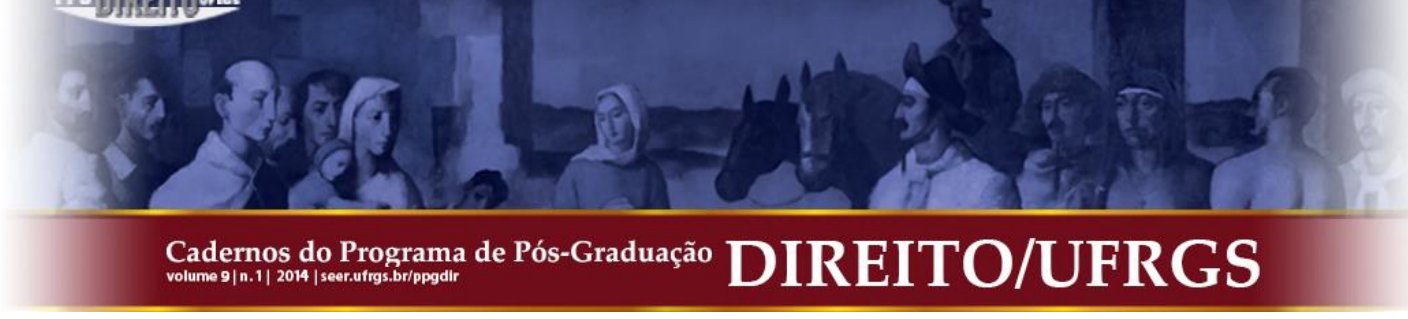

"afetado negativamente ou agravado ... no sentido de qualquer norma relevante" era uma evidente referência à case $l a w^{34}$ envolvendo várias normas específicas que permitiam que qualquer pessoa "afetada negativamente ou agravada" tivesse direito de ação ${ }^{35}$ e que, portanto, alargaram as regras tradicionais nestes campos específicos ${ }^{36}$. (Evidentemente, não se pode ser "afetado negativamente ou agravado no sentido de uma norma" que não contém estas palavras - ou pelo menos palavras substancialmente similares [referindo o dano jurídico a direito da parte $]^{37}$. Da mesma forma, não teria sentido falar-se de alguém difamado "no sentido da Constituição", pois a Constituição não contém a palavra "difamação". Este sentido evidente é embasado em partes da história legislativa dotadas de autoridade - notadamente na declaração do Procurador-Geral Clark $^{38}$, referido no debate no Plenário do Senado pelo Senador McCarran, gestor do Plenário e principal arquiteto da norma ${ }^{39}$, com o efeito de que o

Acesso em 03 mai. 2014, na qual se determinou que: “companhias elétricas privadas não tem direito de ação para contestar a legalidade de empréstimos federais concedidos aos seus concorrentes, pois não houve ofensa a nenhum direito juridicamente reconhecido".

${ }^{34}$ N. do T. Não há como traduzir a expressão case law, pois é peculiar ao common law. A expressão case law abrange a criação jurisprudencial do direito; a sua evolução com base em regras generalizadas a partir de casos concretos, buscando garantir que casos análogos sejam decididos de forma análoga e a própria forma de ver, interpretar, pensar e compreender os fenômenos jurídicos no mundo do common law.

35 ESTADOS UNIDOS. Lei Federal sobre Alimentos, Remédios e Cosméticos, § 401, 52, Stat. 1046 (25/06/1938), codificada com suas alterações na Seção 21 do United States Code, § 346a (i) (1976). ESTADOS UNIDOS. Lei de Utilidade Pública de 1935, § 313(b), 49 Stat. 860 (26/08/1935), codificada com suas alterações na Seção 16 do United States Code $§ 251$ (1982). ESTADOS UNIDOS. Lei Federal de Telecomunicações, § 402 (b) (2), 48 Stat. 1093 (19/06/1934), codificada com suas alterações na Seção 47 do Unites States Code, § 402, (b) (6), (1976).

${ }^{36}$ Compare os casos referidos acima, na nota 34, com ESTADOS UNIDOS. SUPREMA CORTE. FCC v. Sanders Bros. Radio Station, 309 U.S. 470, 476-77 (1940). Disponível em http://supreme.justia.com/cases/federal/us/309/470/case.html. Acesso em 03 mai. 2014, que interpretou o $\$ 402$ (b) da Lei Federal de Telecomunicações, 47 U.S.C. $\$ 402$ (b) (6) (1982), conferindo direito de ação para controle de atos administrativos a "qualquer ... pessoa agravada ou cujos interesses tenham sido afetados adversamente", permitindo que uma estação de rádio contestasse a concessão de uma licença a um competidor.

${ }^{37}$ Havia disposições legislativas referentes ao direito de ação para o controle de atos administrativos que usavam expressões distintas de "pessoa adversamente afetada ou agravada" - veja e.g. ESTADOS UNIDOS. Lei sobre o Comércio Interestadual, 49 U.S.C., § I (20) (1976) ("parte interessada"). Não contraria a intenção evidente do $\S 702$ considerar a frase "pessoa adversamente afetada ou agravada ... no sentido de uma norma relevante" como uma espécie de sinédoque [a sinédoque é uma figura de linguagem na qual se usa um termo referindo uma parte para indicar o todo ou vice-versa], que teria a intenção de abranger também "uma parte interessada ... no sentido de uma norma relevante". Tal interpretação teria o elegante efeito de fazer com que as duas provisões do $\S 702$ ("pessoa sofrendo um dano juridicamente relevante" e "pessoa afetada adversamente ou agravada ... no sentido de uma norma relevante") coincidir precisamente com o que passou a ser conhecido como como "controle judicial de atos administrativos sem fundamento normativo" ( "nonstatutory review") e "controle judicial de atos administrativos com fundamento normativo" ("statutory review"). Veja SCALIA, Antonin. Sovereign Immunity and Nonstatutory Review of Federal Administrative Action: Some Conclusions for the Public-Lands Cases, 68 Mich. L. Rev. 867, 870 (1970).

${ }^{38}$ ESTADOS UNIDOS. SENADO FEDERAL. SENATE REPORT, № 752, $79^{\circ}$ Congresso, $1^{\text {a }}$ Sessão, 44 (1945), reimpressa em ESTADOS UNIDOS. SENADO FEDERAL. Administrative Procedure Act Legislative History, $S$. Doc. $N^{o} 248,79^{\circ}$ Congresso, $2^{a}$ Sessão, 230 (1946)[daqui em diante referido como APA Legislative History].

3992 Cong. Rec. 2153 (1953), APA Legislative History, supra, nota 39, p. 310. 


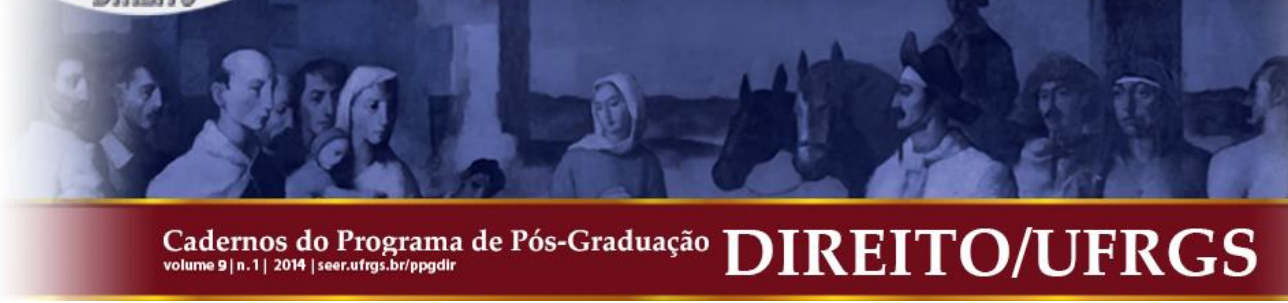

dispositivo referente ao direito de ação para o controle de atos administrativos "reflete o direito existente". [Esta interpretação] também é suportada pelo Manual do Procurador-Geral sobre a Lei do Processo Administrativo (1947), no qual consta: "uma interpretação contemporânea ... confere alguma deferência à [Suprema] Corte, devido ao papel desempenhado pelo Ministério da Justiça no projeto de lei" ${ }^{40}$. Isto indica que o dispositivo era "uma reafirmação do direito existente" 41 . Ao longo dos anos 60, a maioria dos casos adotou esta interpretação simples da norma ${ }^{42}$. Esta interpretação [restritiva] foi repudiada por [duas] decisões da Suprema Corte, ambas prolatadas no mesmo dia, nos casos Association of Data

40 ESTADOS UNIDOS. SUPREMA CORTE. Vermont Yankee Nuclear Power v. Natural Resources Defense Council, Inc., 435 U. S. 519, 546 (1978). Disponível em http://supreme.justia.com/cases/federal/us/435/519/. Acesso em 04 mai. 2014.

${ }^{41}$ ESTADOS UNIDOS. ATTORNEY GENERAL. Attorney's General Manual of the Administrative Procedure Act. Washington, 1947, p. 96.

Deve-se reconhecer, entretanto, que em outros trechos do debate no Plenário do Senado, inclusive em formulações com a concordância do Sen. McCarran (de modo inconsistente com sua citação do ProcuradorGeral), demonstravam o interesse de parte dos membros do Congresso em expandir o controle judicial dos atos administrativos. Veja APA Legislative History, supra, nota 39, pp. 308-311, 318-319, 325-326 e 384 . Estas declarações, algumas das quais tem a aparência de uma história legislativa artificial, simplesmente sobrevoam o texto da norma [aprovada]. Se eles tivessem representado a correta interpretação do projeto de lei, é inconcebível que o Ministério da Justiça não se tivesse oposto a ele. Da mesma forma, é inconcebível que eles possam, isoladamente, formar a base da transferência histórica de poder do Executivo para o Judiciário, que descreveremos abaixo.

${ }^{42} \mathrm{O}$ principal caso foi ESTADOS UNIDOS. WASHINGTON, D. C. APPELLATE COURT. Kansas City Power \& Light Co. v. McKay, 225 F 2d., 924, 932 (D. C. Cir., 1955). Disponível em < http://openjurist.org/225/f2d/924/kansas-city-power-light-company-v-mckay>. Acesso em 04 mai. 2014. Certiorari negado, ESTADOS UNIDOS. SUPREMA CORTE. 350 U. S. 884 (1955). Outros casos com esta visão da Lei do Processo Administrativo foram ESTADOS UNIDOS. UNITED STATES COURT OF APPEALS 8TH CIRCUIT. Association of Data Processing Serv. Orgs. v. Camp., 406 F. 2d. 837, 843 (8th Cir. 1969). Disponível em http://law.justia.com/cases/federal/appellate-courts/F2/406/837/259436/. Acesso em 03 jul. 2014.; ESTADOS UNIDOS. UNITED STATES COURT OF APPEALS 8TH CIRCUIT. Rural Electrification Admin v. Northern States Power Co., 373 F. 2d, 686, $692 \quad \& \quad$ n. 9 ( $8^{\text {th }}$ Cir. 1967). Disponível em http://law.justia.com/cases/federal/appellate-courts/F2/373/686/362509/. Acesso em 03 jul. 2014.; ESTADOS UNIDOS. UNITED STATES COURT OF APPEALS 9TH CIRCUIT. Braude v. Wirtz, 350 F. 2d., 702, 706-08 ( $9^{\text {th }}$ Cir. 1965). Disponível em http://law.justia.com/cases/federal/appellate-courts/F2/350/702/74390/. Acesso em 03 jul. 2014.; ESTADOS UNIDOS. WASHINGTON, D. C. APPELLATE COURT. Gonzales v. Freeman, 334 F 2d. 570, 574-76 (D. C. Cir. 1964). Disponível em http://law.justia.com/cases/federal/appellatecourts/F2/334/570/108798/. Acesso em 03 jul. 2014.; ESTADOS UNIDOS. UNITED STATES COURT OF APPEALS 8TH CIRCUIT. Duba v. Scheutzle, 303 F. 2d., 570, 574-75, ( $8^{\text {th }}$ Cir. 1962). Disponível em http://law.justia.com/cases/federal/appellate-courts/F2/303/570/458175/. Acesso em 03 jul. 2014.; ESTADOS UNIDOS. WASHINGTON, D. C. APPELLATE COURT. Copper Plumbing \& Heating Co. v. Campbell 290 F. 2d. 368, 370-71 (D. C. Cir. 1961).

Em sentido contrário, adotando uma interpretação da Lei do Processo Administrativo parecida com a atualmente empregada pela Suprema Corte, veja ESTADOS UNIDOS. UNITED STATES DISTRICT COURT. SOUTHERN DISTRICT OF NEW YORK. Road Review League v. Boyd, 270 F. Supp. 650, 660-661 (S.D.N.Y. 1967). Disponível em http://law.justia.com/cases/federal/district-courts/FSupp/270/650/1609333/. Acesso em 04 mai. 2014. e ESTADOS UNIDOS. UNITED STATES DISTRICT COURT. DISTRICT OF COLUMBIA. American President Lines v. Federal Maritime Bd., 112 F. Supp. 346, 349 (D.D.C. 1953). Disponível em http://law.justia.com/cases/federal/district-courts/FSupp/112/346/1749174/. Acesso em 04 mai. 2014. 


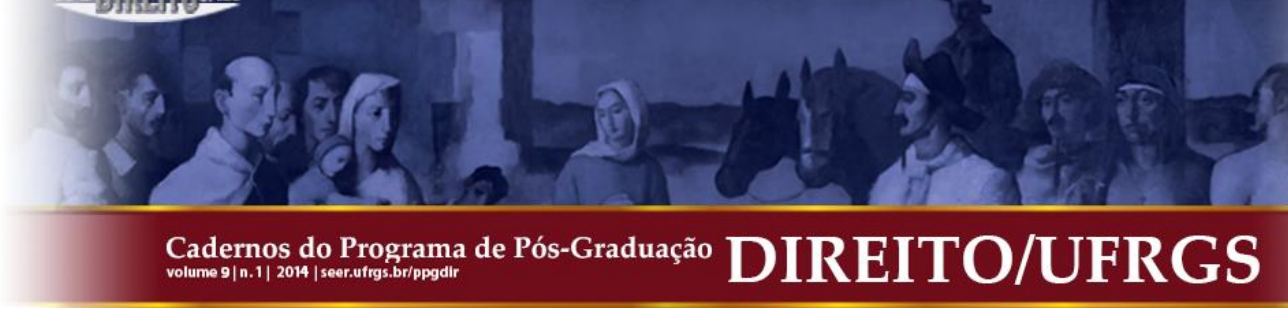

Processing, Inc. v. Camp. ${ }^{43}$ e Barlow v. Collins $^{44}$. Estas decisões da Suprema Corte interpretam "afetado negativamente ou agravado no sentido de uma norma relevante" significando nada mais do que "afetado negativamente ou agravado em um aspecto que uma norma buscou proteger". Em outras palavras, os tribunais converteram o requisito de uma disposição normativa autorizadora do direito de ação para o controle de atos administrativos meramente no requisito de que o autor esteja na "zona de interesse" que a norma busca proteger $^{45}$. Uma incorporação das disposições liberais acerca do direito de ação envolvendo o controle de atos administrativos foi metamorfoseada na garantia do direito de ação em "todas as situações nas quais uma parte que seja de fato agravada busque seu direito de ação para o controle de atos administrativos, independentemente da ausência de um direito legalmente reconhecido ou da linguagem específica de uma norma"46.

É difícil exagerar o efeito que esta interpretação do trecho "afetado negativamente ou agravado" da Lei do Processo Administrativo teve na competência do Judiciário para controlar a atividade do Poder Executivo. Para aquelas atividades das agências abrangidas pela Lei do Processo Administrativo ${ }^{47}$, esta interpretação eliminou, efetivamente, a diferença entre a possibilidade de ajuizamento de ação para o controle de atos administrativos entre as assim denominadas "controle de atos administrativos com base nos generosos permissivos legais, constantes de várias normas de direito material, tais como a Lei Federal da Energia" ("statutory review") e "controle de atos administrativos com base na tradição, na visão mais restritiva de 'dano juridicamente reconhecido', por meio do uso de remédios do common law,

\footnotetext{
${ }^{43}$ ESTADOS UNIDOS. SUPREMA CORTE. Association of Data Processing Services, Inc. v. Camp., 397 U.S. 150, 154-155 (1970). Disponível em http://supreme.justia.com/cases/federal/us/397/150/case.html. Acesso em 03 mai. 2014.

${ }^{44}$ ESTADOS UNIDOS. SUPREMA CORTE. Barlow v. Collins, 397 U. S. 159, 164-165 (1970). Disponível em http://supreme.justia.com/cases/federal/us/397/159/. Acesso em 04 mai. 2014. Veja também ESTADOS UNIDOS. SUPREMA CORTE. Sierra Club v. Morton, 405 U. S. 727, 733 (1972). Disponível em https://supreme.justia.com/cases/federal/us/405/727/case.html. Acesso em 03 mai. 2014, onde a Suprema Corte descreve o caso Data Processing como tendo reformado as decisões dos Tribunais Regionais Federais referidos na nota 43.

${ }^{45}$ ESTADOS UNIDOS. SUPREMA CORTE. Association of Data Processing Services, Inc. v. Camp., 397 U.S. 150, 153-154 (1970). Disponível em http://supreme.justia.com/cases/federal/us/397/150/case.html. Acesso em 03 mai. 2014.; ESTADOS UNIDOS. SUPREMA CORTE. Barlow v. Collins 97 U. S. 159, 164-165 (1970). Disponível em http://supreme.justia.com/cases/federal/us/397/159/. Acesso em 04 mai. 2014.

${ }^{46}$ ESTADOS UNIDOS. WHASHINGTON, D. C. APPELLATE COURT. Scanwell Laboratories, Inc. v. Shaffer 424 F 2d. 859, 872 (D. C. Cir. 1970). Disponível em http://law.justia.com/cases/federal/appellatecourts/F2/424/859/385212/. Acesso em 04 mai. 2014.

${ }^{47}$ Nem todas as ações de todas as agências são cobertas pelas disposições sobre o controle judicial de atos administrativos da Lei do Processo Administrativo. Veja 5 U.S.C. § 701 (1982).
} 


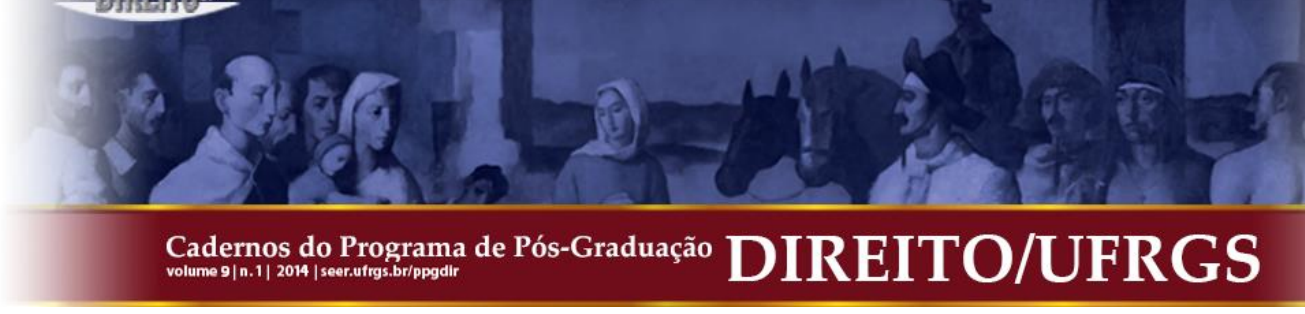

tais como o writ of mandamus ${ }^{48}$ e a injunction" ("nonstatutory review"). De fato, a interpretação da Suprema Corte da Lei do Processo Administrativo teve o inusitado efeito de inverter completamente o esquema pré-existente, fazendo com que muitas disposições legislativas acerca do direito de ação para o controle judicial de atos administrativos restringissem, ao invés de expandir, a possibilidade do ajuizamento de ações que seriam, na ausência destas disposições, viáveis. Portanto, quando o Congresso estabeleceu, na Lei de Controle e de Reclamações sobre a Mineração de Superfície, de 1977, que o controle judicial das regulamentações poderia ser ajuizado por "qualquer pessoa que participasse dos procedimentos administrativos e que seja prejudicada pela ação do Ministro"49, sua intenção era a negar, e não a de conceder direito de ação para a interposição de controle judicial de atos administrativos - ou seja, negar àquelas "pessoas agravadas" que não participaram dos procedimentos administrativos. Em outras palavras, os julgados da Suprema Corte sobre a Lei do Processo Administrativo fizeram com a legislação federal o que os julgados sobre as vendas fizeram com o direito estadual ao produzirem garantias. Assim como a garantia escrita tornou-se, primariamente, uma limitação ao invés de uma extensão da responsabilidade do vendedor; a especificação legislativa do direito de ação para a interposição de medidas judiciais de controle de atos administrativos que contivesse qualquer qualificativo tornou-se uma limitação ao invés de uma concessão da capacidade de opor-se a ação de uma agência.

Quão diminutos são os novos requisitos para o ajuizamento de uma medida judicial de controle administrativo se pode ver no caso $\operatorname{SCRAP}^{50}$, que contestou a falha da Câmara Interestadual de Comércio (ICC) em preparar uma declaração sobre o impacto ambiental antes de autorizar uma sobretaxa sobre o frete ferroviário. O processo foi ajuizado por um grupo de estudantes de direito da Universidade George Washington, que declaravam usar áreas em parques e florestas, cujo uso se tornaria menos agradável pelo incremento de lixo, decorrente da presumida redução do uso de materiais recicláveis, que decorreria da presumida elevação nos custo destes bens, decorrente, por fim, da sobretaxa do frete ferroviário ${ }^{51}$. E se isto não fosse dano suficiente, os autores prejudicados também afirmaram que cada um deles “respirava o ar da área metropolitana de Washington, D. C., a região dos seus domicílios

\footnotetext{
${ }^{48}$ Para uma visão geral do tema veja JAFFE, Louis L. Judicial Control of Administrative Action. Boston: Little, Brown \& Co, 1965, pp. 152-196 (student's edition).

4930 U. S. C. $\$ 1276$ (Supp. III 1979).

50 ESTADOS UNIDOS. SUPREMA CORTE. United States v. Students Challenging Regulatory Agency Procedures, 412 U. S. 669 (1973). Disponível em https://supreme.justia.com/cases/federal/us/412/669/case.html. Acesso em 04 mai. 2014.

${ }^{51}$ Ibidem, p. 676-677.
} 


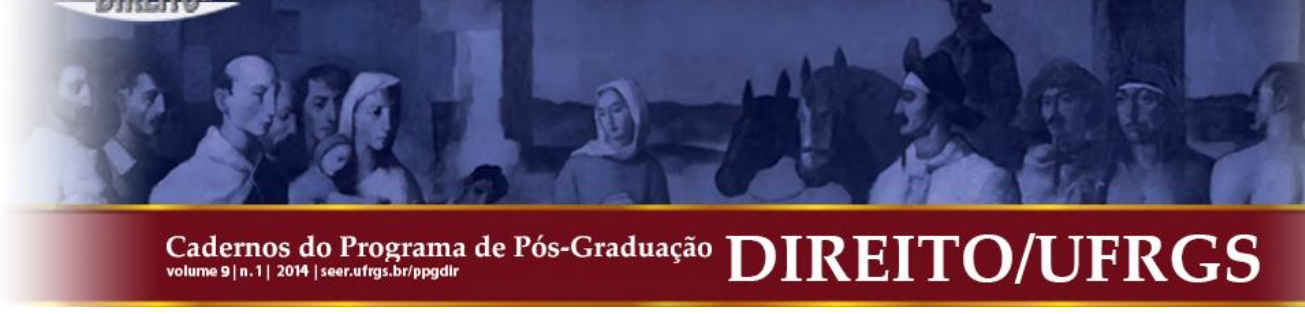

legais, e que este ar teria sofrido uma crescente poluição pela estrutura modificada de taxação" 52 . A Suprema Corte entendeu que estes danos eram suficientes para o ajuizamento da ação ${ }^{53}$. De fato, a Suprema Corte intimou, com respeito a esta ação governamental, "todos aqueles que respirassem o ar [do país]", pois teriam direito de ação ${ }^{54}$.

\section{STANDING E A SEPARAÇÃO DE PODERES}

Até aqui eu tratei da eliminação progressiva, pela Suprema Corte, das denominadas "limitações jurisprudenciais" ao direito de ação. Inevitavelmente, suponho, o elemento "central" - a parte que nem mesmo o Congresso pode eliminar - restringiu-se da mesma forma. O maior desenvolvimento neste aspecto foi a decisão da Suprema Corte em 1968 no caso Flast v. Cohen ${ }^{55}$, que concedeu a um contribuinte federal direito de contestar, com base nas cláusulas sobre o estabelecimento, despesas federais que auxiliavam escolas confessionais. Nunca antes tinha uma má gestão de fundos públicos sido considerada como um "dano" a um contribuinte federal, de modo a conferir-lhe direito de ação. E o motivo, eu afirmo, é que nunca antes tinha a doutrina do Standing sido distanciada da separação de poderes. No voto condutor do caso Flast lêmos:

A "essência da questão do standing" é se a parte buscando um provimento judicial "alegou um interesse pessoal no resultado do processo para assegurar aquela lide concreta que especifica a apresentação das questões das quais o tribunal tanto depende para iluminar complexas questões constitucionais" (Baker v. Carr, 369 U. S. 186 , p. $204(1962)^{56}$... Assim exposto, o requisito do standing está intimamente relacionado com, e é mais geral do que, a regra de que os julgamentos federais não apreciarão processos amigáveis ... nem aqueles que forem simulados ou ajuizados em conluio ...

A questão acerca de se uma pessoa específica é uma parte adequada para manter [ajuizar] uma ação não importa, per si, em problemas relacionados à separação de poderes decorrentes de uma indevida interferência judicial em áreas atribuídas a outros poderes do Governo Federal. Tais problemas decorrem, acaso existam, apenas dos direitos materiais que os indivíduos buscam ajuizar. Portanto, nos termos das limitações ao poder judiciário federal estabelecidas no art. III da CEUA, a questão do direito de ação relaciona-se apenas com a questão de se a

\footnotetext{
52 Ibidem, p. 678.

${ }^{53}$ Ibidem, p. 685.

${ }^{54}$ Ibidem, p. 682.

55 ESTADOS UNIDOS. SUPREMA CORTE. Flast v. Cohen, 392 U. S. 83 (1968). Disponível em http://supreme.justia.com/cases/federal/us/392/83/case.html. Acesso em 04 mai. 2014.

56 ESTADOS UNIDOS. SUPREMA CORTE. Baker v. Carr, 369 U. S. 186, 204 (1962). Disponível em http://supreme.justia.com/cases/federal/us/369/186/case.html. Acesso em 05 mai. 2014.
} 


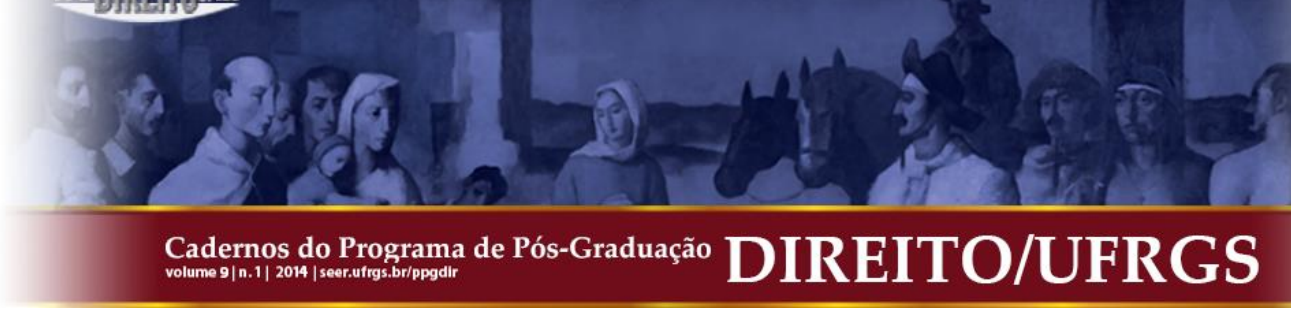

disputa ajuizada será apresentada em um contexto contencioso e em uma forma vista historicamente como adequada para a resolução judicial ${ }^{57}$.

O standing, em outras palavras, busca apenas assegurar que os tribunais possam fazer o seu trabalho bem, e não assegurar que eles se afastem de assuntos que seria melhor deixar com os outros poderes.

Eu devo salientar, inicialmente, (ainda que isto tenha sido dito antes com frequência $)^{58}$, que se o propósito do standing é "assegurar o contencioso concreto que esclarecerá a apresentação dos casos", a doutrina é notadamente mal delineada para este propósito. Frequentemente os melhores adversários são organizações nacionais tais como a NAACP (National Association for the Advancement of Colored People - Associação Nacional para o Avanço dos Afro-Americanos) ou a Associação das Liberdades Civis NorteAmericana que tem um forte interesse na questão abstrata em discussão no processo, mas nenhum "dano jurídico no caso concreto". A doutrina do standing, entretanto, claramente as exclui [a estas associações], a menos que elas possa vincular-se a algum indivíduo particular que acaso tenha um interesse particular (ainda que menor) em jogo ${ }^{59}$.

Nem é verdade, como o caso Flast sugere, que a doutrina do standing não possa ter papel algum na alocação de poder entre os três Poderes desde que ele apenas exclua pessoas e não matérias dos tribunais. Esta análise ignora convenientemente o fato de que, se todas as pessoas que concebivelmente possam ajuizar uma determinada questão sejam excluídas, a matéria também é excluída. O próprio caso Flast demonstra este ponto. Se a determinação de se um gasto federal específico constitui um apoio a uma religião não pode ser levada aos tribunais por meio de um contribuinte federal, é difícil de imaginar quem mais possa ajuizar a questão. A determinação da compatibilidade com a disposição constitucional seria deixada inteiramente à cargo dos Poderes Legislativo e Executivo ${ }^{60}$ - assim como a denegação do direito de ação ao contribuinte atribuiu a estes Poderes a determinação da compatibilidade

\footnotetext{
${ }^{57}$ ESTADOS UNIDOS. SUPREMA CORTE. Flast v. Cohen, 392 U. S. 83, pp. 99-101 (1968). Disponível em http://supreme.justia.com/cases/federal/us/392/83/case.html. Acesso em 04 mai. 2014.

${ }^{58}$ Veja, por exemplo, TRIBE, Lawrence H. American Constitutional Law. 1978, §§ 3-20, p. 90; JAFFE, Louis L. The Citizen as a Litigant in Public Actions: The Non-Hohfeldian or Ideological Plaintiff, 116, U. PA. Law Review, 1033, pp. 1037-1038, 1968; SCOTT, Standing in the Supreme Court - A Funcional Analisys, 86 Harvard Law Review, 645, pp. 673-674, 1973.

${ }^{59}$ Veja ESTADOS UNIDOS. SUPREMA CORTE. Sierra Club v. Morton, 405 U.S. 727, 731 (1972). Disponível em https://supreme.justia.com/cases/federal/us/405/727/case.html. Acesso em 03 mai. 2014

${ }^{60}$ Evidentemente, quando a subvenção a uma religião tiver o efeito de restringir ou coagir as crenças religiosas individuais, ela poderia ser questionada em juízo sob a cláusula da "liberdade religiosa" da $1^{a}$ Emenda, mas esta é uma questão diferente. Veja ESTADOS UNIDOS. SUPREMA CORTE. McCollum v. Board of Education, 333 U. S. 203 (1948). Disponível em http://supreme.justia.com/cases/federal/us/333/203/case.html. Acesso em 07 mai. 2014.
} 


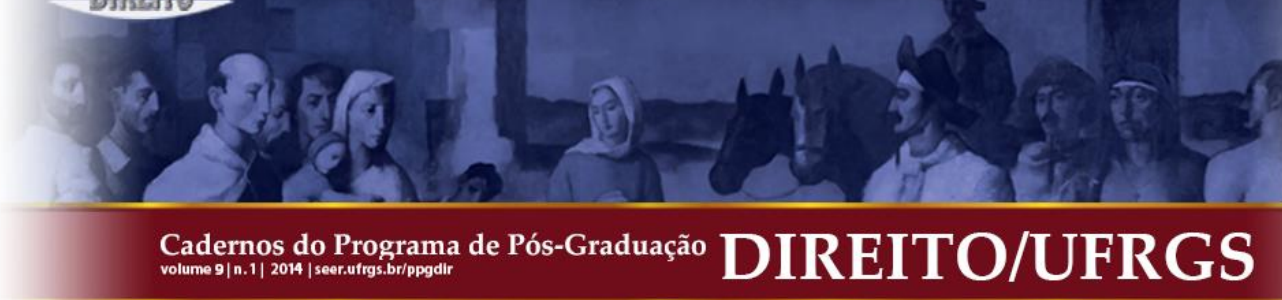

com o requisito constitucional de que "uma Declaração regular e a Contabilização das Receitas e Despesas de toda a Receita Pública ... seja publicada periodicamente" ${ }^{\text {"61 }}$.

Mesmo que fosse verdade que a doutrina do standing nunca excluísse inteiramente matérias da apreciação judicial, ela ainda teria um enorme efeito no relacionamento entre os poderes. O grau no qual os tribunais se converteram em cortes políticas depende não somente de que matérias são admitidas para ajuizamento, mas também de quando e de sob qual autoria os órgãos o judiciário podem conhece-las. Como De Tocqueville observou:

\begin{abstract}
Veremos ... que deixando a cargo do interesse privado a censura do direito, e pela união intrínseca do julgamento do direito com o julgamento de um indivíduo, a legislação fica protegida de assaltos arbitrários e das agressões diárias do espírito partidário. Os erros do legislador são expostos apenas para fazer face a uma necessidade real; e é sempre um fato concreto e apreciável que deve servir como base para um ajuizamento ${ }^{62}$.
\end{abstract}

A grande mudança ocorrida no papel do Judiciário nos últimos anos decorre em parte da sua competência para analisar matérias que antes se considerava estarem fora do âmbito do judiciário. Na minha opinião, entretanto, esta mudança decorre, em uma medida pelo menos igual, da capacidade dos tribunais de analisar tanto as novas quanto as antigas matérias prontamente, sob o patrocínio de praticamente qualquer pessoa que tenha um interesse em jogo. Não tem sentido colocar os tribunais em uma disputa sobre políticas públicas depois do final da batalha, ou depois que o entusiasmo que a produziu se esgotou. A condição sine qua non da emergência dos tribunais como um parceiro igual dos Poderes Executivo e Legislativo na formulação de políticas públicas foi a garantia do acesso imediato aos tribunais por aqueles interessados na condução do debate. A sociedade advocatícia dedicada em tempo integral aos interesses públicos, tão permanentemente envolvida quanto o lobby em tempo integral junto ao Congresso, tornou-se um fenômeno generalizado apenas nas últimas décadas não porque antes os tribunais não podiam apreciar questões que afetassem profundamente as políticas públicas; mas principalmente porque antes deste tempo a possibilidade de apresentar estas questões livremente (para fazer "ataques voluntariosos", utilizando a caracterização pejorativa de De Tocqueville) era drasticamente circunscrita [limitada]. A mudança foi efetivada por vários meios, incluindo alguns desenvolvimentos aparentemente não relacionados entre si

61 ESTADOS UNIDOS DA AMÉRICA. CONSTITUIÇÃO (1787). Washington: Senate, [2014], art. I, § 9, cláusula 7. Disponível em http://www.senate.gov/civics/constitution_item/constitution.htm. Acesso em 28 abr. 2014. Veja também ESTADOS UNIDOS. SUPREMA CORTE. United States v. Richardson, 418 U. S. 166 (1974). Disponível em http://supreme.justia.com/cases/federal/us/418/166/. Acesso em 07 mai. 2014.

${ }^{62}$ TOCQUEVILLE, Alexis de. Democracy in America. [s.1.]: T. Bradley, 1945, p. 102. 


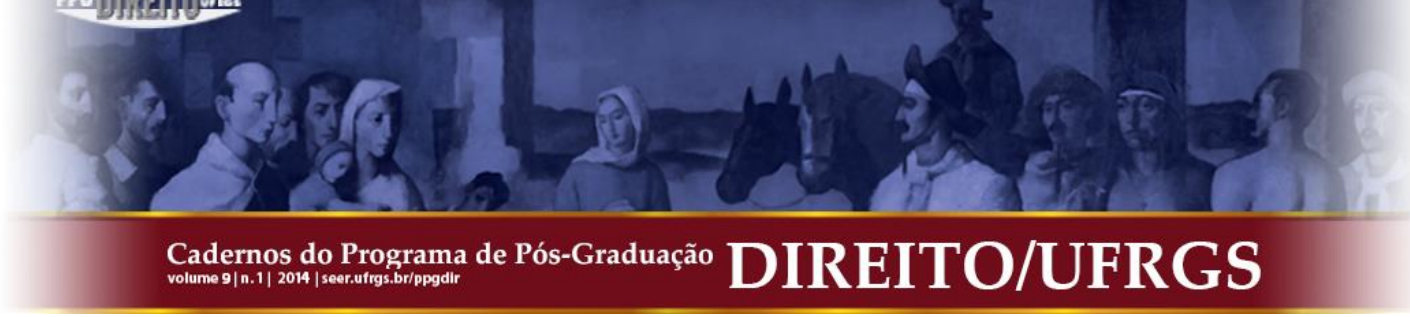

como a limitação do escopo constitucionalmente permissível das normas contra a litigância de risco ["champerty and maintenance"] ${ }^{63}$ (de forma que a matéria possa agora encontrar mais prontamente uma vítima representável), a mudança na doutrina da causa madura ${ }^{64}$ (“ripeness") ${ }^{65}$ (de forma que demandas que antes eram consideradas prematuras possam agora ser ajuizadas de imediato) e - para retornar ao ponto - alteração na doutrina do standing ${ }^{66}$.

${ }^{63}$ N. do T. Champerty é um acordo entre o autor e outrem, normalmente um advogado, que concorda em financiar e encarregar-se do processo, em troca de um percentual do retorno (dinheiro ganho e pago). Esse tipo de acordos eram ilegais no common law, pois se supunha que encorajavam a litigância. Hoje são admitidos e normalmente integram o acordo de "encargos de contingência" entre o advogado e o seu cliente. Distingue-se de barratry que é o encorajamento ativo do ajuizamento. Cf. http://legaldictionary.thefreedictionary.com/Champerty, acesso em 7 mai. 2014.

Maintenance é o apoio ao litigante por um terceiro sem justa causa. Champerty é uma forma agravada de maintenance. A característica distintiva de champerty é o apoio ao processo em troca de um percentual do resultado. No common law, ambos - maintenance e champerty - eram ilícitos civis (dando origem à responsabilidade civil - tort) e criminais. Cf. http://en.wikipedia.org/wiki/Champerty_and_maintenance, acesso em 7 mai. 2014.

Barratry, no common law, é a ofensa cometida por pessoas que são "excessivamente laboriosas na instigação ou no encorajamento do ajuizamento de processos sem fundamento" ou que "cometem repetidos ou persistentes atos de ajuizamento" com o propósito de lucro ou perseguição. É considerada crime em algumas jurisdições. Se a litigância tem o propósito de silenciar críticos, é conhecida como Strategic Lawsuit Against Public Participation (SLAPP - Litigância Estratégica Contra a Participação Pública). Mesmo os ordenamentos que não possuem previsão para a punição da barratry podem prever a punição da SLAPP. Nos EUA, vários estados tipificaram penalmente a barratry, no sentido de litigância frívola ou persecutória, como parte de seus esforços na reforma da responsabilidade civil. Na Califórnia, na Virgínia, e no Estado de Washington a barratry é uma contravenção. No Texas é uma contravenção na primeira condenação, passando a ser punida como crime em caso de reincidência. Cf. http://en.wikipedia.org/wiki/Barratry_(common_law)\#United_States, acesso em 7 mai. 2014.

${ }^{64}$ Veja, e. g. ESTADOS UNIDOS. SUPREMA CORTE. Abbot Laboratories v. Gardner, 387 U. S. 136, 148-49 (1967). Disponível em http://supreme.justia.com/cases/federal/us/387/136/case.html. Acesso em 08 mai. 2014.

${ }^{65} \mathrm{~N}$. do T. Nos EUA uma causa está madura para o julgamento ("a claim is ripe") quando os fatos sob julgamento evoluíram para uma controvérsia de direito material que permite o ajuizamento da demanda. $\mathrm{O}$ art. III, seção 2, cláusula 1 da Constituição dos EUA (CEUA) exige que os tribunais federais decidam causas e controvérsias. A exigência de que uma demanda esteja madura para o controle judicial é um aspecto da jurisdição de direito material relacionado intimamente com o requisito do standing. A questão da maturidade para julgamento ocorre com frequência em casos nos quais o dano alegado pelo autor ainda não ocorreu [demandas preventivas, monitórias, proibitórias etc.]. Como os tribunais não podem decidir nem questões meramente hipotéticas nem possibilidades, o juízo deve determinar se a causa é passível de controle judicial, ou se o desenvolvimento posterior dos fatos não tornará a causa mais concreta. Cf. http://www.law.cornell.edu/wex/ripe, acesso em 7 mai. 2014.

${ }^{66}$ Um quadro completo de como surgiram as mudanças no papel dos tribunais teria de incluir, além dos demais desenvolvimentos judiciais tratados no texto, também os desenvolvimentos legislativos. Particularmente, as amplas garantias do direito de ação no que pertine ao controle judicial de atos administrativos. O Congresso não apenas concordou com a releitura da Lei do Processo Administrativo pelo judiciário, como pressionou os tribunais a avançarem neste caminho, distribuindo direitos de ação em normas de direito material com uma liberalidade que excede a releitura judicial da Lei do Processo Administrativo. Nos últimos anos, o Congresso provavelmente até entrou em conflito com o entendimento da Suprema Corte que mantém uma escassa limitação "central" [da exigência] do dano real. Na Lei de Segurança dos Produtos ao Consumidor, de 1972, por exemplo, o Congresso não se contentou em conferir o direito de ação para questionar as regras da Comissão a "qualquer pessoa adversamente afetada"; aduzindo "ou qualquer consumidor ou organização de consumidores" (U.S. C., § 2060(a)), uma expressão que pareceria redundante caso se referisse apenas ao consumidor do produtor em questão. Em 1975, na Lei Magnuson-Moss, o Congresso preparou-se para ir ainda mais longe: 


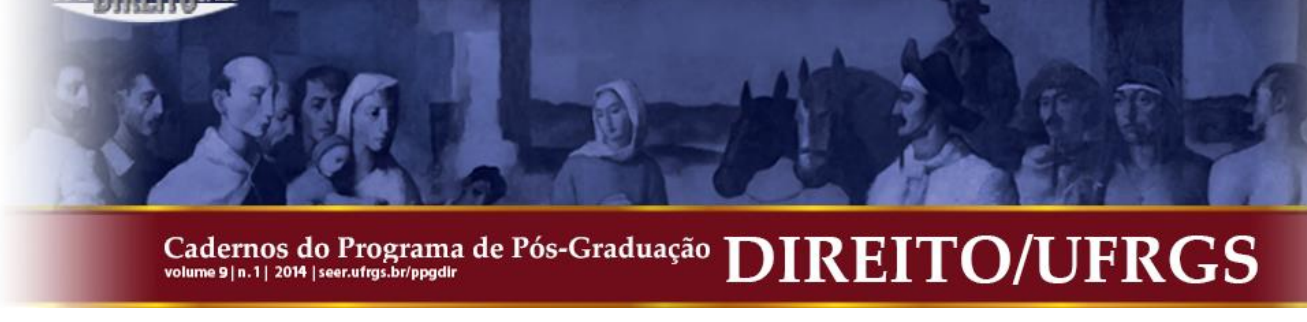

\section{A SEPARAÇÃO DE PODERES E OS DIREITOS DOS INDIVÍDUOS}

Tendo demonstrado (assim o espero), que a doutrina do standing afeta, efetivamente, a separação de poderes, passo à questão de se o modo como ela o faz tem algum sentido. É o standing relacionado funcionalmente com o papel distintivo que esperamos que os tribunais (e juízes) executem? Esta questão não tem interesse apenas acadêmico, pois se houver uma relação funcional ela pode ter alguma influência sobre o modo como as questões envolvendo o direito de ação são decididos nos casos particulares.

Acredito que haja uma relação funcional, que pode ser melhor descrita dizendo-se que o direito do standing restringe as cortes rigorosamente ao seu tradicional papel ademocrático de proteger os indivíduos e as minorias contra as imposições da maioria, excluindo os órgãos do judiciário do papel ainda mais antidemocrático de prescrever como os outros dois Poderes devem operar para servir aos interesses da maioria propriamente dita. Portanto, quando um indivíduo, que é o próprio objeto da determinação ou da proibição normativa, buscar contestála, ele terá sempre direito de ação. Este é o caso clássico da norma derrotando ao próprio indivíduo, e o judiciário não parará para inquirir se a "lesão" é generalizada ${ }^{67}$.

Compare a forma clássica de desafio judicial com os casos cada vez mais comuns nos quais o autor reclama de uma falha antijurídica das agências administrativas na imposição de

Não mais de 60 (sessenta) dias após a promulgação de uma norma ... qualquer pessoa interessada (incluindo um consumidor ou organização de consumidores), por protocolar uma petição ... para o controle judicial [e de constitucionalidade] desta norma.

15 U.S.C. $§ 57 \mathrm{a}(\mathrm{e})(1)$. A expressão "pessoa interessada" não significa mais do que ela diz. A mesma linguagem foi utilizada na Lei de Segurança dos Produtos ao Consumidor, de 1972, seção 10(a), 15 U.S.C. § 2059 (1976), para descrever quem estaria habilitado a participar do processo legislativo diante da comissão, e a história legislativa desta disposição deixa bem claro que não do que uma atração intelectual é necessária para qualificar uma pessoa como "interessada". Veja ESTADOS UNIDOS. CÂMARA DOS DEPUTADOS. HOUSE OF REPRESENTATIVES REPORT. N ${ }^{\circ}$ 92-1593, 92d Cong. 2d Sess., p. 47 (1972); ESTADOS UNIDOS. SENADO FEDERAL. SENATE REPORT. 92-835, 92d, Cong., 2. Sess., p. 14 (1972). O termo é utilizado com sentido similar na Lei do Processo Administrativo. Compare 5 U. S. C. § 553(c) com 5 U. S. C. $§ 702$. Não é minha intenção aqui discutir desenvolvimentos legislativos, mas tenho de observar que a aprovação e até mesmo o encorajamento do Congresso não podem validar o desrespeito aos limites entre o segundo e o terceiro poderes. A situação lembra o que $O$ Federalista chamou de "uma combinação de dois Poderes contra o terceiro" (Federalista, artigo 49, de James Madison).

67 Veja ESTADOS UNIDOS. UNITED STATES ILLINOIS NORTHERN DISTRICT COURT. Matz v. United States, 581 F. Supp. 714 (N. D. III 1984). Disponível em http://law.justia.com/cases/federal/districtcourts/FSupp/581/714/1596907/. Acesso em 08 mai. 2014. 


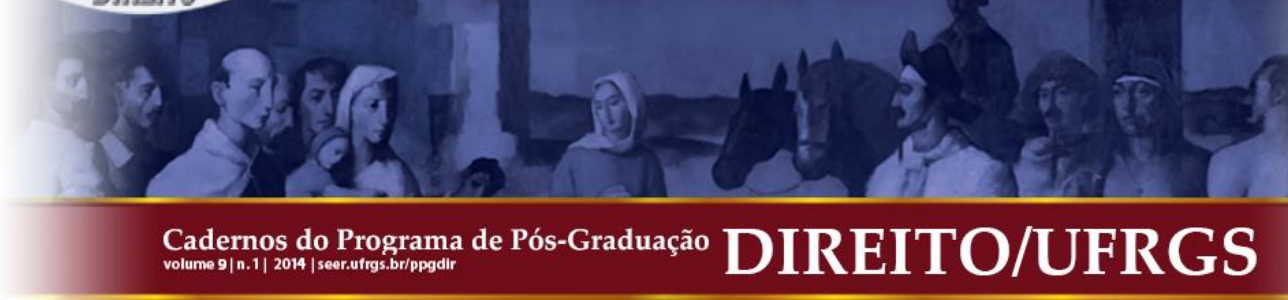

uma determinação proibitiva sobre um terceiro $^{68}$. Uma falha deste tipo prejudica o autor, privando-o, como um cidadão, de atos governamentais exigidos pela Constituição e pelo direito infraconstitucional. O dano é, entretanto, da espécie majoritária. O autor pode importar-se com ele, pode ser um ardente defensor da regularidade constitucional ou da necessidade do ato governamental que foi erroneamente omitido. Isto, entretanto, não o torna especificamente atingido - apenas atesta que o autor avalia o dano mais gravemente, o que é um assunto típico para o debate democrático no qual ele pode persuadir o resto de nós. Como a nossa disposição a sermos persuadidos não é menor do que a do autor ([pois] fomos tão afetados quanto ele) não há motivo para retirar o assunto do processo político e colocá-lo nos tribunais. A menos que o autor possa demonstrar algum aspecto no qual ele foi mais afetado do que o resto de nós (por exemplo, se ele for um trabalhador em um canteiro de obras específico onde a Administração de Segurança e Saúde Ocupacional tenha erroneamente afastado exigências de segurança) ele não terá estabelecido nenhum fundamento para preocupação que a maioria tenha suprimido ou ignorado os direitos de uma minoria que busque proteção, e portanto não cumpriu os pré-requisitos para a intervenção judicial.

Isto explica, acredito eu, porque um "dano concreto" - um dano além da mera quebra do contrato social, que se pode dizer que tenha sido afetado pelo próprio fato da ação governamental antijurídica - é o requisito indispensável do standing. Apenas o que pode separar o autor de todo o resto de nós, que também podemos solicitar o benefício do contrato social, é que pode, portanto, intitulá-lo ao recebimento de alguma proteção especial diante do modo democrático pelo qual nós normalmente gerimos nossos assuntos envolvendo o contrato social. Evidentemente, a dano concreto é um requisito necessário, mas não é uma condição necessariamente suficiente. $\mathrm{O}$ autor precisa comprovar não apenas o seu status de minoria, mas um status de minoria relevante diante da transgressão governamental que ele busca corrigir. Se o dano concreto que ele sofrerá em decorrência de uma falha governamental em observar o direito é puramente fortuito - no sentido de que as normas não foram especificamente planejadas para evitar o dano, mas antes para outro propósito (normalmente mais geral) - então a falha da maioria em exigir a observância do direito não pode ser tida como dirigida contra ele, e a sua pretensão de proteção especial desaparece. Esta é a questão essencial conduzida sob o título de indagar-se se o autor que busca o direito de ação sofreu

\footnotetext{
${ }^{68}$ Veja ESTADOS UNIDOS. SUPREMA CORTE. Schlesinger v. Reservists Commitee to Stop the War, 418 U.
} S. 208 (1974). Disponível em http://supreme.justia.com/cases/federal/us/418/208/. Acesso em 08 mai. 2014. 
algum "dano juridicamente reconhecido" ("legal wrong") 69 ; ou se ele se enquadra na definição de parte "adversamente afetada" ou "agravada" conforme disposto nas várias normas de direito material que empregam estas expressões; ou se ele está dentro de uma "zona de interesses" protegida por uma norma de direito material sob a interpretação decorrente da distorção da Lei do Processo Administrativo após o caso Data Processing ${ }^{70}$.

Se eu estiver correto no sentido de que a doutrina do standing, como aplicada às contestações à ação governamental, é um meio essencial de restringir o judiciário ao seu papel assinalado de proteção de uma minoria, ao invés dos interesses da maioria, várias consequências podem ser delineadas. Primeiramente, uma consequência de algum interesse teórico, mas relativamente com pouco efeito prático: ocorreria que nem todos os "danos concretos" que decorressem indiretamente da ação ou da inação governamentais estariam amparados pelo deferimento, pelo Congresso, do direito de ação. Podemos conceber um dano concreto tão amplamente compartilhado que uma especificação pelo Congresso de uma norma que fosse destinada a evitar precisamente esta espécie de dano fosse, não obstante, insuficiente para delimitar um subgrupo do corpo político que necessitasse de proteção judicial. Por exemplo, ações governamentais apontadas como errôneas que afetassem "todos que respiram"71. Certamente não há razão para acreditar que uma omissão governamental de impacto tão geral não receba justa consideração no processo político normal.

Uma consequência mais prática pertine não ao poder do Congresso em conferir direito de ação, mas à interpretação judicial da intenção do Congresso a este respeito. Se a doutrina do standing servir, de fato, à separação de poderes, tal como eu sugiro, então no processo de resposta à abstrusa questão de se "dano juridicamente reconhecido" ("legal wrong") foi cometido, ou se uma pessoa é "adversamente afetada ou agravada", de forma que haja direito de ação, o judiciário deve ter em mente o objeto desta tarefa, e não deve inclinar-se a aceitar a designação, pelo Congresso, de um "grupo minoritário" tão amplo que abranja praticamente toda a população. Eu tenho em mente um caso recente que encontrou uma intenção do Congresso em conferir direito de ação a um grupo não menos extenso que todos os

\footnotetext{
${ }^{69}$ Veja acima a nota 34 e o texto que a acompanha.

${ }^{70}$ N. do T. Veja acima, a nota 46 e o texto que a acompanha.

${ }^{71}$ Veja ESTADOS UNIDOS. SUPREMA CORTE. United States v. Students Challenging Regulatory Agency

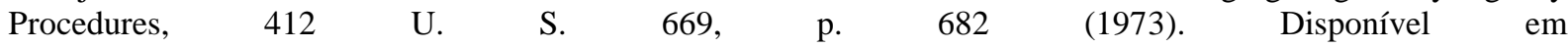
https://supreme.justia.com/cases/federal/us/412/669/case.html. Acesso em 04 mai. 2014.
} 


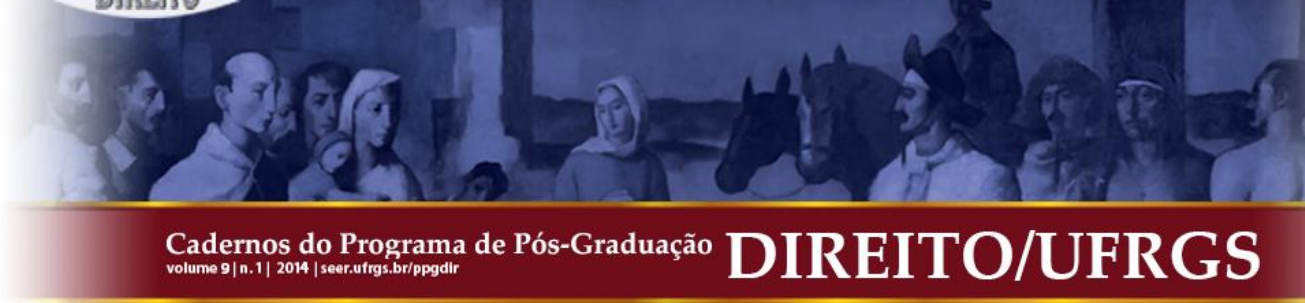

consumidores de leite ${ }^{72}$. É difícil de acreditar que o processo democrático, caso ele funcione de alguma forma, não possa e não dava ser digno de crédito quanto à proteção dos interesses deste grupo que inclui a quase todos.

Mas eis a questão final: mesmo se a doutrina do standing significou, no passado, a restrição dos juízes "a decidir, somente, direitos individuais"73, o que haveria de errado em deixá-los proteger também os direitos da maioria? Se eles foram tão bem em um campo, porque não promovê-los para o outro? A resposta é que não há razão para acreditar que eles tenham qualquer capacidade para isto. De fato, eles foram especificamente pensados como sendo ruins nisto - selecionados da aristocracia ou altamente educados, instruídos para serem governados por um corpo de conhecimentos que valoriza princípios abstratos acima dos resultados concretos e (apenas no caso de que qualquer conexão com o homem da rua possa subsistir) subtraídos de qualquer responsabilidade perante o eleitorado. Isto é perfeito para um corpo de funcionários destinado a proteger o indivíduo frente ao povo; mas é terrível (a menos que você seja um monarquista) para um grupo que se espera que decida o que é bom para o povo. Onde os tribunais, no suposto interesse de todo o povo, exigem a obediência do Executivo a políticas legislativas que o próprio processo político não exige, eles estão provavelmente (apesar das melhores intenções) apoiando preconceitos políticos de sua própria classe. O seu maior sucesso em tal tarefa - assegurar a obediência estrita às normas ambientais, não para proteger minorias específicas, mas para o benefício de toda a população - foi vista com aprovação nas salas de aula de Cambridge e New Haven, mas não nas fábricas de Detroit e nas minas da Virgínia Ocidental. Pode bem ser, é claro, que o juízes saibam o que é melhor para o povo mais do que a própria população; ou que a democracia simplesmente não permita que os desejos genuínos do povo tenham efeito; mas estas não são as premissas sob as quais o nosso sistema opera.

O que eu disse significa que, enquanto não haja interesses minoritários em jogo, “importantes propósitos legislativos, proclamados no hall do Congresso, [possam ser] abandonados ou deturpados nos amplos corredores da burocracia federal"? É evidente que sim - e isto é bom, também. Onde não houver dano específico a indivíduos ou minorias em jogo,

\footnotetext{
${ }^{72}$ ESTADOS UNIDOS. WASHINGTON, D. C. APPELLATE COURT. Community Nutrition Inst. v. Block, 698 F. 2d. 1239 (D. C. Cir. 1984). Certiorari conferido, ESTADOS UNIDOS. SUPREMA CORTE. 52 U. S. L. W. 3422 (1984). Disponível em http://supreme.justia.com/cases/federal/us/467/340/case.html. Acesso em 08 mai. 2014.

${ }^{73}$ ESTADOS UNIDOS. SUPREMA CORTE. Marbury v. Madison, 5 U. S. (1 Cranch) 137, p. 170 (1803). Disponível em http://supreme.justia.com/cases/federal/us/5/137/case.html. Acesso em 05 mai. 2014.
} 
vários propósitos proclamados no passado devem ser abandonados ou deturpados, nos vastos corredores ou em qualquer outro lugar. A prioridade de ontem é o aborrecimento de hoje embora nós, juízes, na reclusão de nossas câmaras, podemos não estar atualizados o bastante para percebê-lo. A habilidade para abandonar ou deturpar normas pode ser tida como uma das máquinas primárias da mudança social, e a proibição contra estes descuidos é (acredite ou não) profundamente conservadora. Normas que restringiam ou proibiam o comércio aos domingos por motivos religiosos (Sunday blue laws), por exemplo, deixaram de ser aplicadas e exigidas por muito tempo antes de serem completamente revogadas - e se o primeiro não tivesse sido possível, o segundo poderia nunca ter ocorrido.

\section{RETORNO AO ENTENDIMENTO ORIGINAL}

No início dos anos 70 - depois que o caso Flast decidiu que a doutrina do standing "não levanta, por si, problemas para a separação de poderes relacionados à interferência judicial em áreas atribuídas a outros poderes do governo federal"74, e após os casos Data Processing ${ }^{75}$, Barlow v. Collins ${ }^{76}$ e SCRAP $^{77}$ demonstrarem a intenção da Suprema Corte de operar com base neste pressuposto - o assunto tratado no presente artigo teria mero interesse histórico. Ele pode ter o seu título alterado para “A Antiga Relevância do Standing para a Separação de Poderes”. Desde aquele tempo, entretanto, a teoria [do standing] da Suprema Corte retornou a sua tradição, e há razão para acreditar que sua prática também retornará [à tradição]. O comentário efetuado fora da ratio decidendi [em dictum] no caso Flast foi repudiado por decisões que reconhecem explicitamente que o standing e a separação de poderes estão intimamente relacionados ${ }^{78}$. E o elemento essencial que liga os dois - a

\footnotetext{
${ }^{74}$ ESTADOS UNIDOS. SUPREMA CORTE. Flast v. Cohen, 392 U. S. 83, pp. 100-01 (1968). Disponível em http://supreme.justia.com/cases/federal/us/392/83/case.html. Acesso em 04 mai. 2014.

${ }^{75}$ ESTADOS UNIDOS. SUPREMA CORTE. Association of Data Processing Services, Inc. v. Camp., 397 U. S. 150 (1970). Disponível em http://supreme.justia.com/cases/federal/us/397/150/case.html. Acesso em 03 mai. 2014.

76 ESTADOS UNIDOS. SUPREMA CORTE. Barlow v. Collins, 397 U. S. 159 (1970). Disponível em http://supreme.justia.com/cases/federal/us/397/159/. Acesso em 04 mai. 2014.

77 ESTADOS UNIDOS. SUPREMA CORTE. United States v. Students Challenging Regulatory Agency Procedures, 412 U. S. 669 (1973). Disponível em https://supreme.justia.com/cases/federal/us/412/669/case.html. Acesso em 04 mai. 2014.

78 ESTADOS UNIDOS. SUPREMA CORTE. Valley Forge Christian College v. Americans United for the Separation of Church and State, Inc., 454 U. S. 464, pp. 471-74 (1982). Disponível em http://supreme.justia.com/cases/federal/us/454/464/. Acesso em 08 mai. 2014; ESTADOS UNIDOS. SUPREMA CORTE. Warth v. Seldin, 422 U. S. 490, p. 498 (1975). Disponível em http://supreme.justia.com/cases/federal/us/422/490/. Acesso em 08 mai. 2014.
} 


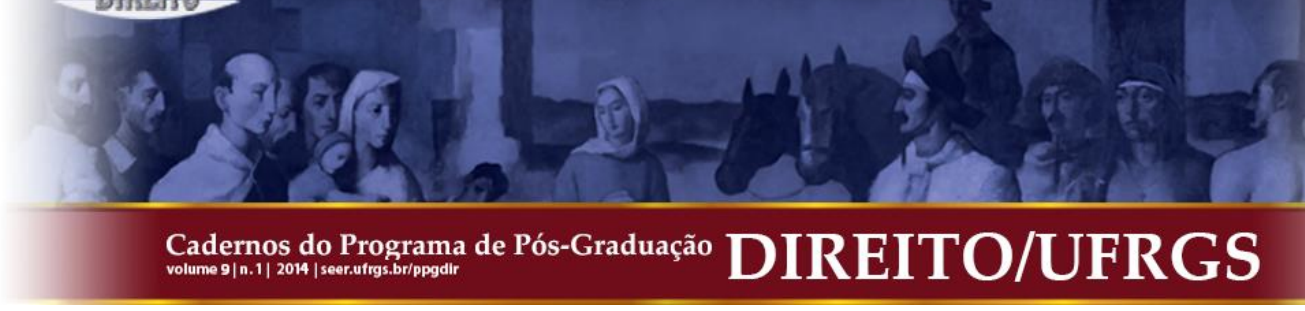

exigência de dano específico não compartilhado por todo o corpo político - ressuscitou. A decisão do caso Flast foi essencialmente a repudia à decisão Frothingham v. Mellon ${ }^{79}$, no qual a Suprema Corte não permitiu que um contribuinte discutisse, em juízo, gastos efetuados em violação à cláusula de comércio, pois não era suficiente alegar dano sofrido em "algum modo indefinido em comum com o povo em geral" ${ }^{100}$. Em casos mais recentes, entretanto, como em United States v. Richardson ${ }^{81}$ e Schlesinger v. Reservists Commitee to Stop the $W{ }^{82}$, não apenas repuseram a decisão de Frothingham no seu lugar de honra, como citaram a seguinte passagem do venerável caso Ex Parte Lévitt ${ }^{83}$ :

É um princípio estabelecido que para habilitar um indivíduo privado a invocar o Poder Judiciário para determinar a validade de uma ação do Executivo ou do Legislativo ele deve demonstrar que sofreu ou que está na iminência de sofrer um dano direto como resultado desta ação, não sendo suficiente que ele tenha apenas um interesse comum com todos os membros da população ${ }^{84}$.

É improvável que esta reversão à antiga teoria não leve a algum de retorno à antiga prática. Aparentemente, o caso Flast já foi limitado estritamente aos seus fatos ${ }^{85}$, e eu antecipo que a disposição da Suprema Corte da era do caso SCRAP para discernir embasamentos amplíssimos para o direito de ação com base em motivações do Congresso não vai durar. Já há indicações disto em decisões demonstrando relutância em “deduzir” em

79 ESTADOS UNIDOS. SUPREMA CORTE. Frotingham v. Mellon, 262 U. S. 447 (1923). Disponível em https://supreme.justia.com/cases/federal/us/262/447/case.html. Acesso em 08 mai. 2014.

${ }^{80}$ Ibidem, p. 448.

${ }^{81}$ ESTADOS UNIDOS. SUPREMA CORTE. United States v. Richardson, 418 U. S. 166, pp. 171-74 (1974). Disponível em http://supreme.justia.com/cases/federal/us/418/166/. Acesso em 08 mai. 2014.

82 ESTADOS UNIDOS. SUPREMA CORTE. Schlesinger v. Reservists Commitee to Stop the War, 418 U. S. 208, p. 220, n. 8 (1974). Disponível em http://supreme.justia.com/cases/federal/us/418/208/. Acesso em 08 mai. 2014.

${ }^{83}$ ESTADOS UNIDOS. SUPREMA CORTE. Ex Parte Levitt, 302 U. S. 633 (1937), relato sumário do caso disponível em http://en.wikipedia.org/wiki/Ex_parte_Levitt. Acesso em 08 mai. 2014.

${ }^{84}$ Ibidem, p. 634, citado em ESTADOS UNIDOS. SUPREMA CORTE. United States v. Richardson, 418 U. S. 166, pp. 177-178 (1974). Disponível em http://supreme.justia.com/cases/federal/us/418/166/. Acesso em 08 mai. 2014 e em ESTADOS UNIDOS. SUPREMA CORTE. Schlesinger v. Reservists Commitee to Stop the War, 418 U. S. 208, pp. 219-20 (1974). Disponível em http://supreme.justia.com/cases/federal/us/418/208/. Acesso em 08 mai. 2014.

${ }^{85}$ A Suprema Corte se refere a isto como "o rigor com que a exceção do caso Flast ... deve ser aplicado". ESTADOS UNIDOS. SUPREMA CORTE. Valley Forge Christian College v. Americans United for Separation of Church and State, Inc., 454 U. S. 464, p. 481 (1982). Disponível em http://supreme.justia.com/cases/federal/us/454/464/. Aacesso em 08 mai. 2014. A base para a distinção da decisão (distinguishing) Flast tanto no caso Valley Forge, 454 U. S. pp. $479-480$ como no caso Richardson, 418 U. S. pp. 174-175, disponível em http://supreme.justia.com/cases/federal/us/418/166/, acesso em 08 mai. 2014 são diferenças que parecem completamente irrelevantes diante do que o caso Flast busca atingir. A Suprema Corte parece ter seguido a sugestão do Ministro Powell no caso Richardson, que ela "limite a expansão do direito de ação aos contribuintes e cidadãos na ausência de autorização normativa específica para a utilização de limites mais amplos, tal como se vê pelos resultados no caso Flast e no caso Baker v. Carr" 418 U. S. p. 196 (voto de Powell, J., acompanhando o voto condutor). 


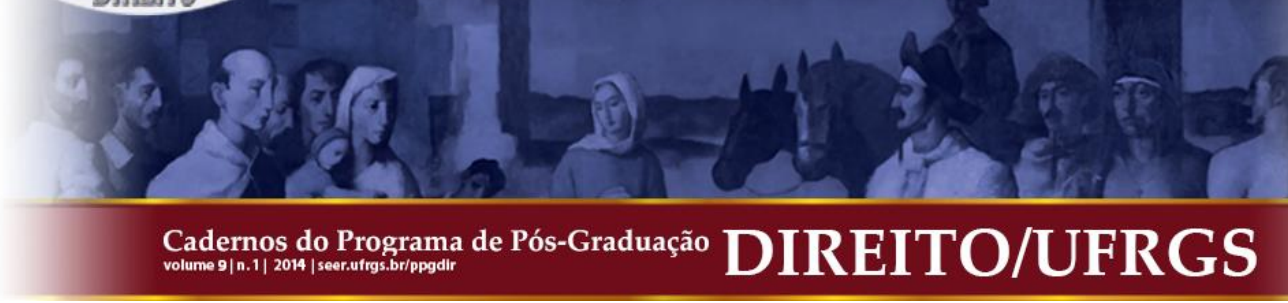

normas federais direitos de ação contra festas particulares ${ }^{86}$, cujas decisões também foram referidas no contexto de processos contra funcionários públicos ${ }^{87}$. Embora a expressão "adversamente afetado ou agravado no sentido de uma norma relevante" da Lei do Processo Administrativo provavelmente não venha a ser restaurada ao seu sentido original, a expressão efetivamente substituída "adversamente afetado ou agravo no sentido de uma norma relevante" (envolvendo a aplicação do teste das assim denominadas "zonas de interesse") deixa muita margem de manobra. Eu espero que a direção desta manobra seja no sentido da separação de poderes ${ }^{88}$.

${ }^{86}$ Veja, e. g. ESTADOS UNIDOS. SUPREMA CORTE. California v. Sierra Club, 451 U. S. 287, pp. 292-98 (1981). Disponível em http://supreme.justia.com/cases/federal/us/451/287/case.html. Acesso em 08 mai. 2014; ESTADOS UNIDOS. SUPREMA CORTE. Transamerica Mortgage Advisors, Inc. v. Lewis, 444 U. S. 11, pp. 19-25 (1979). Disponível em http://supreme.justia.com/cases/federal/us/444/11/case.html. Acesso em 08 mai. 2014; ESTADOS UNIDOS. SUPREMA CORTE. Touche Ross \& Co. v. Redington, 442 U. S. 560, pp. 575-76 (1979). Disponível em https://supreme.justia.com/cases/federal/us/442/560/case.html. Acesso em 08 mai. 2014.

${ }^{87}$ Veja, e. g. ESTADOS UNIDOS. SUPREMA CORTE. California v. Sierra Club, 451 U. S. 287 (1981). Disponível em http://supreme.justia.com/cases/federal/us/451/287/case.html. Acesso em 08 mai. 2014, mas veja ESTADOS UNIDOS. UNITED STATES COURT OF APPEALLS 9TH CIRCUIT. California v. Watt, 683 F. 2d. 1254 , p. 1270 (9th Cir. 1982), relato da decisão disponível na íntegra no sítio https://scholarsbank.uoregon.edu/xmlui/bitstream/handle/1794/10391/coastal_memo_3.pdf?sequence=1. Acesso em 08 mai. 2014; ESTADOS UNIDOS. UNITED STATES COURT OF APPEALLS 9TH CIRCUIT. Glacier Park Foundation v. Watt, 663 F. 2d. 882, pp. 884-85 (9th Cir. 1981). Disponível em http://law.justia.com/cases/federal/appellate-courts/F2/663/882/146924/. Acesso em 08 mai. 2014.

${ }^{88}$ N. do T. Buscando uma apreciação global da evolução da doutrina americana do standing desde a publicação deste artigo, em 1983, fornecemos o panorama abaixo, que parece seguir a direção apontada por Scalia.

Em 1992 foi decidido o leading case Lujan (Lujan v. Defenders of Wildlife, 112 S. Ct. 2130 (1992)) no qual " $a$ decisão da Suprema Corte, voltada inteiramente à análise do direito de ação, é extremamente simples. Ela tem quatro partes: uma declaração geral sobre o standing; uma discussão sobre o dano real; uma avaliação do conflito de competência e um tratamento do processo pelo cidadão. A declaração geral inicia com uma descrição da função do standing em um sistema de separação de poderes. De acordo com a Suprema Corte, o art. III da Constituição dos EUA contém um 'núcleo constitucional mínimo do standing', com três elementos: (1) um dano real que seja tanto (a) concreto e particularizado e (b) atual ou iminente ao invés de conjectural ou hipotético; (2) uma demonstração de que o dano pode ser imputado aos atos do réu, ao invés de a uma terceira pessoa; e (3) uma demonstração de que é provável que o dano seja reduzido por uma decisão favorável ao autor. Esta declaração inicial traz pouca novidade. A Suprema Corte, entretanto, aduziu que a questão do standing será frequentemente afetada pelo fato de 'se o autor é ele mesmo o objeto da ação (ou omissão) em questão. Se o autor é o objeto [da ação], os três requisitos normalmente estarão presentes, mas quando o 'dano decorre de uma regulação (ou da sua ausência) governamental apontada como contrária ao direito, de uma regulação de outrem, exige-se muito mais. [...] A Suprema Corte sugeriu que nestes casos o standing é muito mais difícil de estabelecer. [...] Da mesma forma, não há direito de ação para alguém que demonstre interesse no estudo de espécies ameaçadas, seja em função de um compromisso empregatício ou por outro motivo qualquer. Deve haver "uma demonstração fática de dano perceptivel"' (SUNSTEIN, Cass R. What's Standing After Lujan? Of Citizen Suits, 'Injuries' and Article III. Michigan Law Review, 91, p. 163-236, especialmente pp. 198-199, tradução nossa).

Em um artigo escrito em 2008 na conceituada Stanford Law Review (ELLIOT, Heather. The Functions of Standing. Stanford Law Review, 61, n. 3, 2008), Elliot Heather salienta que a Suprema Corte norte-americana, há décadas, utiliza a doutrina do standing para promover várias funções úteis à separação de poderes, restringindo o judiciário aos casos que possuem lides concretas para a resolução judicial, evitando questões melhor respondidas pelo outros Poderes e auxiliando o judiciário a resistir aos esforços do Congresso em arregimentar o judiciário em sua luta contra o Executivo, na mesma linha do artigo de Scalia. A autora, entretanto, acha que a doutrina do standing não é o meio mais eficiente para a separação dos poderes e a correta delimitação do Poder Judiciário, 


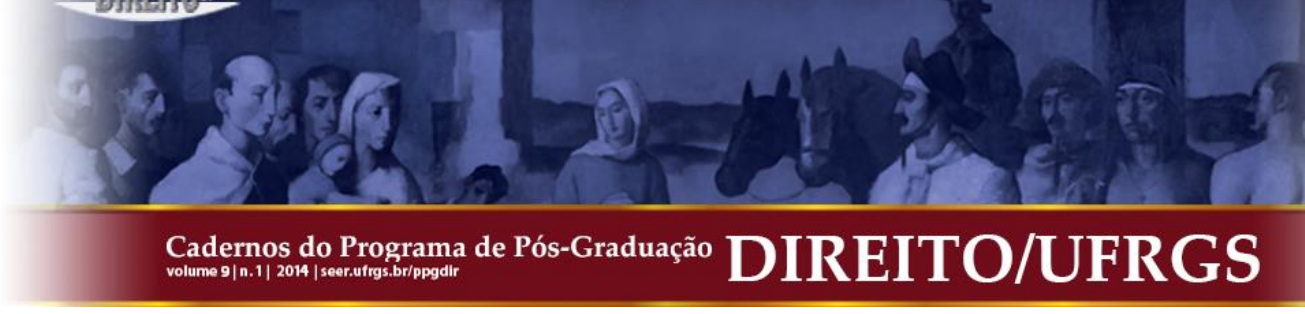

\section{REFERÊNCIAS}

CHAYES, Abram. The Role of the Judge in Public Law Litigation. Harvard Law Review, vol. 89, p. 1.281, 1976.

ESTADOS UNIDOS. Constituição (1787). Washington: Senate, [2014]. Disponível em: http://www.senate.gov/civics/constitution_item/constitution.htm. Acesso em: 06 mai. 2014.

Lei Federal de Telecomunicações, § 402 (b) (2), 48 Stat. 1093 (19/06/1934), codificada com suas alterações na Seção 47 do Unites States Code, § 402, (b) (6), (1976).

Lei de Utilidade Pública de 1935, § 313(b), 49 Stat. 860 (26/08/1935), codificada com suas alterações na Seção 16 do United States Code $§ 251$ (1982).

Lei Federal sobre Alimentos, Remédios e Cosméticos, § 401, 52, Stat. 1046 (25/06/1938), codificada com suas alterações na Seção 21 do United States Code, § 346a (i) (1976).

. Administrative Procedure Act (APA). Lei de 11 de junho de 1946, cap. 324, 60. Lei

237, 243, 5 United States Code $\$ 702$ (1982). Disponível em: http://uscode.house.gov/view.xhtml?req=granuleid:USC-prelim-title5section702\&num=0\&edition=prelim. Acesso em: 04 mai. 2014.

Lei sobre o Comércio Interestadual, 49 U.S.C., § I (20) (1976).

\footnotetext{
insistindo em um tratamento mais detalhado das questões políticas, que seria, na sua visão, de mais claro entendimento para os juízes de primeiro grau, pois a doutrina do Standing é muito complexa e não completamente coerente, pois baseada em um número muito grande de regras criadas por casos específicos, com pontos de sobreposição e contradição ainda não resolvidos.

Jonathan Siegel, em 2007, argumentando que a doutrina do standing evoluiu no sentido da restrição excessiva ao direito de ação, propõe um retorno parcial à visão anterior, relaxando os requisitos do standing, mas mantendo a limitação do papel das cortes e respeitando a não apreciação de questões políticas pelo judiciário. No mesmo sentido de Heather Elliot, Siegel entende que a doutrina das questões políticas é mais simples e menos confusa do que a do standing, mas admite que o standing é o principal critério para a limitação do judiciário hoje. Siegel entende que o critério material das questões políticas (pp. 112-113) seria mais adequado que o processualmaterial do standing (pp. 138-139). O autor salienta que Scalia desenvolveu sua doutrina do standing tanto neste artigo quanto no famoso caso Lujan (p. 98-99) acima analisado, bem como em alguns votos vencidos posteriores. (SIEGEL, Jonathan R. A Theory of Justiciability. Texas Law Review, Austin, Texas: Texas Law

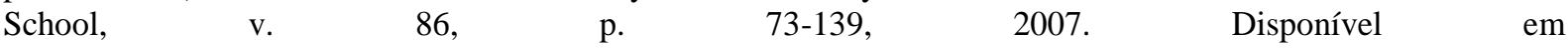
<http://docs.law.gwu.edu/facweb/jsiegel/publications/justiciability.pdf>. Acesso em 28 abr. 2014.
} 
ESTADOS UNIDOS. ATTORNEY GENERAL. Attorney's General Manual of the Administrative Procedure Act. Washington, 1947.

ESTADOS UNIDOS. CÂMARA DOS DEPUTADOS. HOUSE OF REPRESENTATIVES REPORT. No 92-1593, 92d Cong. 2d Sess., p. 47 (1972).

ESTADOS UNIDOS. SENADO FEDERAL. SENATE REPORT, $\mathrm{N}^{\mathrm{o}} 752,79^{\circ}$ Congresso, $1^{\mathrm{a}}$ Sessão, 44 (1945).

Administrative Procedure Act Legislative History, S. Doc. $\mathrm{N}^{\circ} 248,79^{\circ}$ Congresso, $2^{\mathrm{a}}$ Sessão, 230 (1946). SENATE REPORT. 92-835, 92d, Cong., 2. Sess., p. 14 (1972).

ESTADOS UNIDOS. SUPREMA CORTE. Hayburn's Case, 2 U. S. (2. Dall.) 409 (1792). Disponível em: http://supreme.justia.com/cases/federal/us/2/409/. Acesso em: 04 mai. 2014.

. Marbury v. Madison, 5 U. S. (1 Cranch) 137 (1803). Disponível em: http://supreme.justia.com/cases/federal/us/5/137/case.html. Acesso em: 05 mai. 2014.

- United States v. Ferreira, 54 U. S. (13 How) 40 (1851). Disponível em: http://supreme.justia.com/cases/federal/us/54/40/case.html. Acesso em: 04 mai. 2014.

Muskrat v. United States, 219 U. S. 346, 1911. Disponível em: https://supreme.justia.com/cases/federal/us/219/346/case.html. Acesso em: 04 mai. 2014.

Frotingham v. Mellon, 262 U. S. 447 (1923). Disponível em: https://supreme.justia.com/cases/federal/us/262/447/case.html. Acesso em: 08 mai. 2014.

Ex Parte Levitt, 302 U. S. 633 (1937), relato sumário do caso Disponível em: http://en.wikipedia.org/wiki/Ex_parte_Levitt. Acesso em: 08 mai. 2014.

Alabama Power Co. v. Ickes, 302 U.S. 464, 479-80 (1938). Disponível em: https://supreme.justia.com/cases/federal/us/302/464/case.html. Acesso em: 03 mai. 2014 
Tennesse Elec. Power Co. v. TVA, 306 U. S., 118, 137-38 (1939) (notas de rodapé omitidas). Disponível em: http://supreme.justia.com/cases/federal/us/306/118/case.html. Acesso em: 03 mai. 2014.

FCC v. Sanders Bros. Radio Station, 309 U.S. 470, 476-77 (1940). Disponível em: http://supreme.justia.com/cases/federal/us/309/470/case.html. Acesso em: 03 mai. 2014

Perkins v. Lukens Steel Co., 310 U. S. 113, 125 (1940). Disponível em: https://supreme.justia.com/cases/federal/us/310/113/case.html. Acesso em: 03 mai. 2014

Stark v. Wickard, $321 \quad$ U. $\quad$ S. 288 (1944). Disponível em: http://supreme.justia.com/cases/federal/us/321/288/case.html. Acesso em: 05 mai. 2014.

McCollum v. Board of Education, 333 U. S. 203 (1948). Disponível em: http://supreme.justia.com/cases/federal/us/333/203/case.html. Acesso em: 07 mai. 2014.

350 U. S. 884 (1955).

. Baker v. Carr, 369 U. S. 186, 204 (1962). Disponível em: http://supreme.justia.com/cases/federal/us/369/186/case.html. Acesso em: 05 mai. 2014.

$$
384 \quad \text { US } 941 \quad \text { (1966). Disponível }
$$

em:

http://supreme.justia.com/cases/federal/us/386/372/case.html. Acesso em: 03 mai. 2014.

. Abbot Laboratories v. Gardner, 387 U. S. 136, 148-49 (1967). Disponível em: http://supreme.justia.com/cases/federal/us/387/136/case.html. Acesso em: 08 mai. 2014.

Flast v. Cohen, 392 U. S. 83 (1968). Disponível em: http://supreme.justia.com/cases/federal/us/392/83/case.html. Acesso em: 04 mai. 2014.

Association of Data Processing Services, Inc. v. Camp., 397 U.S. 150, 154 (1970). Disponível em: http://supreme.justia.com/cases/federal/us/397/150/case.html. Acesso em: 03 mai. 2014.

Barlow v. Collins, 397 U. S. 159, 164-165 (1970). Disponível em: http://supreme.justia.com/cases/federal/us/397/159/. Acesso em: 04 mai. 2014. 
Sierra Club v. Morton, 405 U.S. 727, 1972. Disponível em: https://supreme.justia.com/cases/federal/us/405/727/case.html. Acesso em: 03 mai. 2014.

. Trafficante v. Metropolitan Life Ins. Co., 409 US 205, 212 (1972) (voto do Ministro de White, J., acompanhando o voto condutor). Disponível em: http://supreme.justia.com/cases/federal/us/409/205/. Acesso em: 03 mai. 2014.

United States v. Students Challenging Regulatory Agency Procedures, 412 U. S. 669 (1973). Disponível em: https://supreme.justia.com/cases/federal/us/412/669/case.html. Acesso em: 04 mai. 2014.

. United States v. Richardson, 418 U. S. 166 (1974). Disponível em: http://supreme.justia.com/cases/federal/us/418/166/. Acesso em: 07 mai. 2014.

Schlesinger v. Reservists Commitee to Stop the War, 418 U. S. 208 (1974). Disponível em: http://supreme.justia.com/cases/federal/us/418/208/. Acesso em: 08 mai. 2014.

mai. 2014.

. Warth v. Seldin, 422 US 490, 512-14 (1975). Disponível em: http://supreme.justia.com/cases/federal/us/422/490/. Acesso em: 03 mai. 2014.

. Vermont Yankee Nuclear Power v. Natural Resources Defense Council, Inc., 435 U. S. 519, 546 (1978). Disponível em: http://supreme.justia.com/cases/federal/us/435/519/. Acesso em: 04 mai. 2014.

Touche Ross \& Co. v. Redington, 442 U. S. 560, pp. 575-76 (1979). Disponível em: https://supreme.justia.com/cases/federal/us/442/560/case.html. Acesso em: 08

Transamerica Mortgage Advisors, Inc. v. Lewis, 444 U. S. 11, pp. 19-25 (1979). Disponível em: http://supreme.justia.com/cases/federal/us/444/11/case.html. Acesso em: 08 mai. 2014

. California v. Sierra Club, 451 U. S. 287, pp. 292-98 (1981). Disponível em: http://supreme.justia.com/cases/federal/us/451/287/case.html. Acesso em: 08 mai. 2014 
Valley Forge Christian College v. Americans United for the Separation of Church and State, Inc., 454 U. S. 464, pp. 471-74 (1982). Disponível em: http://supreme.justia.com/cases/federal/us/454/464/. Acesso em: 08 mai. 2014

$52 \quad U . \quad$ S. $\quad$ L. $\quad W . ~ 3422 \quad$ (1984). Disponível em: http://supreme.justia.com/cases/federal/us/467/340/case.html. Acesso em: 08 mai. 2014.

ESTADOS UNIDOS. UNITED STATES COURT OF APPEALS 2ND CIRCUIT. United States Cane Sugar Refiners' Ass'n v.McNutt, 138, F. 2d. 116, 119-120 (2d. Circ. 1943). Disponível em: http://law.justia.com/cases/federal/appellate-courts/F2/138/116/1481644/. Acesso em: 03 mai. 2014.

American Lecithin Co. v. McNutt, 155 F 2d. 784, 785 (2d. Circ. 1946). Disponível em: http://law.justia.com/cases/federal/appellate-courts/F2/155/784/1563758/. Acesso em: 03 mai. 2014.

Scenic Hudson Preservation Conference v. FPC, 354 2d 608 (2d Circ. 1965). Disponível em: http://law.justia.com/cases/federal/appellate-courts/F2/354/608/151121/. Acesso em: 03 mai. 2014.

ESTADOS UNIDOS. UNITED STATES COURT OF APPEALS 8TH CIRCUIT. Duba v. Scheutzle, 303 F. 2d., 570, 574-75, $\left(8^{\text {th }}\right.$ Cir. 1962). Disponível em: http://law.justia.com/cases/federal/appellate-courts/F2/303/570/458175/. Acesso em: 03 jul. 2014.

. Rural Electrification Admin v. Northern States Power Co., 373 F. 2d, 686, 692 \& n. 9 ( ${ }^{\text {th }}$ Cir. 1967). Disponível em: http://law.justia.com/cases/federal/appellatecourts/F2/373/686/362509/. Acesso em: 03 jul. 2014.

Association of Data Processing Serv. Orgs. v. Camp., 406 F. 2d. 837, 843 (8th Cir. 1969). Disponível em: http://law.justia.com/cases/federal/appellatecourts/F2/406/837/259436/. Acesso em: 03 jul. 2014.

UNIDOS. UNITED STATES COURT OF APPEALS 9TH CIRCUIT. Braude v. Wirtz, 350 F. 2d., 702, 706-08 (9 $9^{\text {th }}$ Cir. 1965). Disponível em: http://law.justia.com/cases/federal/appellate-courts/F2/350/702/74390/. Acesso em: 03 jul. 2014. 
Glacier Park Foundation v. Watt, 663 F. 2d. 882, pp. 884-85 (9th Cir. 1981). Disponível em: http://law.justia.com/cases/federal/appellate-courts/F2/663/882/146924/. Acesso em: 08 mai. 2014.

. California v. Watt, 683 F. 2d. 1254, p. 1270 (9th Cir. 1982), relato da decisão

disponível na íntegra no sítio https://scholarsbank.uoregon.edu/xmlui/bitstream/handle/1794/10391/coastal_memo_3.pdf?se quence $=1$. Acesso em: 08 mai. 2014

ESTADOS UNIDOS. UNITED STATES DISTRICT COURT. DISTRICT OF COLUMBIA. American President Lines v. Federal Maritime Bd., 112 F. Supp. 346, 349 (D.D.C. 1953). Disponível em: http://law.justia.com/cases/federal/district-courts/FSupp/112/346/1749174/. Acesso em: 04 mai. 2014.

ESTADOS UNIDOS. UNITED STATES DISTRICT COURT. SOUTHERN DISTRICT OF NEW YORK. Road Review League v. Boyd, 270 F. Supp. 650, 660-661 (S.D.N.Y. 1967). Disponível em: http://law.justia.com/cases/federal/district-courts/FSupp/270/650/1609333/. Acesso em: 04 mai. 2014.

ESTADOS UNIDOS. UNITED STATES ILLINOIS NORTHERN DISTRICT COURT. Matz v. United States, 581 F. Supp. 714 (N. D. III 1984). Disponível em: http://law.justia.com/cases/federal/district-courts/FSupp/581/714/1596907/. Acesso em: 08 mai. 2014.

ESTADOS UNIDOS. WASHINGTON, D. C. APPELLATE COURT. Kansas City Power \& Light Co. v. McKay, 225 F 2d., 924, 932 (D. C. Cir. 1955). Disponível em: < http://openjurist.org/225/f2d/924/kansas-city-power-light-company-v-mckay>. Acesso em: 04 mai. 2014. 1961).

Copper Plumbing \& Heating Co. v. Campbell 290 F. 2d. 368, 370-71 (D. C. Cir.

. Gonzales v. Freeman, 334 F 2d. 570, 574-76 (D. C. Cir. 1964). Disponível em: http://law.justia.com/cases/federal/appellate-courts/F2/334/570/108798/. Acesso em: 03 jul. 2014.

Scanwell Laboratories, Inc. v. Shaffer 424 F 2d. 859, 872 (D. C. Cir. 1970). Disponível em: http://law.justia.com/cases/federal/appellate-courts/F2/424/859/385212/. Acesso em: 04 mai. 2014. 
Calvert Cliffs Coordinating Comm'n v. Atomic Energy Comm'n, 449 F. 2d. 1109 (D.C. Cir. 1971). Disponível em: http://law.justia.com/cases/federal/appellatecourts/F2/449/1109/240994/. Acesso em: 05 mai. 2014.

Community Nutrition Inst. v. Block, 698 F. 2d. 1239 (D. C. Cir. 1984).

FULLER, Lon L. The Forms and Limits of Adjudication. Harvard Law Review, vol. 92, n. 2, Dec. 1978, pp. 353-409. Disponível em: http://www.jstor.org/discover/10.2307/1340368?uid=3737664\&uid=2129\&uid=2\&uid=70\&u $\mathrm{id}=4 \& \operatorname{sid}=21101310094827$. Acesso em: 20/11/2011.

HAMILTON, Alexander; MADISON, James \& JAY, John. The Federalist. Indianapolis: Liberty Fund, 2001.

HOROWITZ, Donald L. The Courts and Social Policy. Washington, D. C.: The Brookings Institution, 1977.

JAFFE, Louis L. Judicial Control of Administrative Action. Boston: Little, Brown \& Co, 1965 (student's edition).

The Citizen as a Litigant in Public Actions: The Non-Hohfeldian or Ideological Plaintiff, 116, U. PA. Law Review, 1033, pp. 1037-1038, 1968.

MASSACHUSETTS. Constituição (1780). Boston: The General Court, 2014. Disponível em: https://malegislature.gov/Laws/Constitution. Acesso em: 06 mai. 2014.

SCALIA, Antonin. Sovereign Immunity and Nonstatutory Review of Federal Administrative Action: Some Conclusions for the Public-Lands Cases, 68 Mich. L. Rev. 867, 870 (1970).

SCOTT, Standing in the Supreme Court - A Funcional Analisys, 86 Harvard Law Review, 645, pp. 673-674, 1973.

TOCQUEVILLE, Alexis de. Democracy in America. [s.1.]: T. Bradley, 1945.

TRIBE, Lawrence H. American Constitutional Law. 1978. 
Submissão: 30/06/2013

Aceito para Publicação: 30/06/2013 